TI 2012-063/3

Tinbergen Institute Discussion Paper
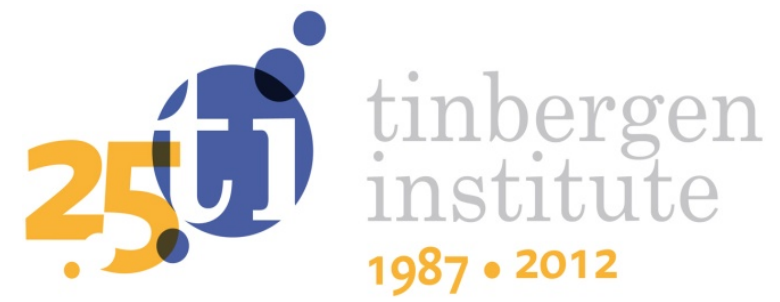

\title{
Revealed Competition for Greenfield Investments between European Regions
}

\author{
Martijn J. Burgerl,2 \\ Bert van der Knaap ${ }^{1,2}$ \\ Ronald S. Walll,3
}

1 Erasmus University Rotterdam;

2 Erasmus School of Economics;

3 Institute for Housing and Urban Studies. 
Tinbergen Institute is the graduate school and research institute in economics of Erasmus University Rotterdam, the University of Amsterdam and VU University Amsterdam.

More TI discussion papers can be downloaded at http://www.tinbergen.nl

Tinbergen Institute has two locations:

Tinbergen Institute Amsterdam

Gustav Mahlerplein 117

1082 MS Amsterdam

The Netherlands

Tel.: +31(0)205251600

Tinbergen Institute Rotterdam

Burg. Oudlaan 50

3062 PA Rotterdam

The Netherlands

Tel.: +31(0)10 4088900

Fax: $+31(0) 104089031$

Duisenberg school of finance is a collaboration of the Dutch financial sector and universities, with the ambition to support innovative research and offer top quality academic education in core areas of finance.

DSF research papers can be downloaded at: http://www.dsf.nl/

Duisenberg school of finance

Gustav Mahlerplein 117

1082 MS Amsterdam

The Netherlands

Tel.: +31(0)20 5258579 


\title{
Revealed Competition for Greenfield Investments between European Regions
}

\section{Martijn J. Burger}

Corresponding author: Department of Applied Economics, Erasmus University Rotterdam and Tinbergen Institute, P.O. Box 1738, 3000 DR Rotterdam. Tel: +31 (0)10 4089579. Fax: +31 (0)10 4089141. E-mail: mburger@ese.eur.nl. URL: http://www.mjburger.net

\section{Bert van der Knaap}

Department of Applied Economics, Erasmus University Rotterdam and ERIM. E-mail: vanderknaap@ese.eur.nl

\section{Ronald S. Wall}

Institute for Housing and Urban Studies, Erasmus University Rotterdam. E-mail: wall@ihs.nl

\begin{abstract}
In the modern economy, cities are assumed to be in fierce competition over attracting foreign investments in leading sectors of the world economy. Despite the rich theoretical discourse on these 'wars', it remains unclear which territories are competing with each other over which types of investments Combining insights from international economics, international business, and urban systems literature, we develop an indicator to measure revealed competition between territories for investments based on the overlap of investment portfolios of regions. Taking competition for greenfield investments between European regions as a test subject, we identify competitive market segments, derive the competitive threat a region faces from other regions, the competitive threat regions pose to other regions, and the most important market segments in which regions compete. We show that European regions with similar locational endowments pose a fiercer competitive threat to one another. In addition, regions that are sufficiently large and distinctive, face the smallest average competitive threat from all other regions.
\end{abstract}




\section{Introduction}

In a globalising world in which the mobility of capital steadily increases, cities and regions increasingly compete over drawing multinational corporations (MNCs) to their territory. These 'place wars' can take place at local, regional, national, continental, or even global spatial scales (Gordon, 1999). To boost their economies and increase their standards of living, cities and regions have to work on their ability to successfully compete with other territories (i.e., competitive advantage) over attracting foreign investments in leading sectors of the world economy (Storper, 1997; Kitson et al., 2004). ${ }^{1}$ Today, local and regional governments not only use incentive-based policies (e.g., subsidies, taxes) but also capacity-building policies such as government spending on amenities, education, physical infrastructure, and public transportation networks to foster the attractiveness of their territory (Begg, 1999). At the same time, taking advantage of a territory's sources of competitive advantage has moved to the central stage in local and regional development policy: the marketing and branding of cities and regions has become a 'booming business' (Paddison, 1993; Van der Berg and Braun, 1999), while budgets for place promotion are ever increasing (LeRoy, 2005; Markusen and Nesse, 2007).

The increasing interest in urban and regional competitive advantage has resulted in a substantial number of ranking lists, in which cities and regions are compared on the basis of their internal characteristics, such as their economic performance (Kresl and Singh, 1999), global connectivity (Taylor, 2004), creativity and innovativeness (Florida, 2005), and quality of life (Rogerson, 1999). This benchmarking of cities and regions is not only found in academia and commercial research but is also strongly embedded in public policy and popular culture. Today, local authorities increasingly publicise their relative competitive stance with that of other areas (Malecki, 2002; Kitson et al., 2004), while many magazines (e.g., Fortune Magazine, Forbes, Money) seem to be obsessed with rankings how cities and regions compare to each other (McCann, 2004). In this light, several studies and policy reports have also addressed the competitive advantage of territories in attracting foreign investments (e.g., UNCTAD, 2001).

Nevertheless, in the discussion on urban and regional competition, it remains unclear which territories are competing with each other over which types of investments. In other words, most studies that present performance rankings of cities and regions implicitly assume that all cities and regions compete to the same extent with each other and little attention is 
paid to identifying the scope and intensity of territorial competition. This assumption is not surprising, as competition is often conceptualised as a characteristic of a market in economics, and therefore, all local and regional governments would compete over foreign investments. Still, the 'market for investments' is highly segmented or, at best, not a level playing field (Phelps and $\mathrm{Wu}, 2009$ ). Despite the increasing mobility of capital, only a limited number of locations can satisfy the criteria of an MNC that would like to invest in a particular project abroad (Lall and Pietrobelli, 2002; Dunning and Narula, 2004; Narula and Bellak, 2009). This fact is reflected in the location choice process of MNCs, in which the majority of all potential locations in the world are not even considered by company site selectors (Aharoni, 1966; Buckley et al., 2007; Mataloni Jr., 2010). ${ }^{2}$

The need to focus on capitalising particular potentials that a city or region has is increasingly recognised and anticipated by local and regional development agencies that try to attract specific foreign investments to their territory and to articulate distinctive assets of their region in promotional marketing (Young et al., 1994; Raines, 2004). In this respect, cities and regions have also become aware that foreign investments are not a sine qua non for economic growth (Mencinger, 2003; Barba Navaretti and Venables, 2004) and that it is best to attract investments that complement their economic structure to profit most from spillovers (Dunning and Narula, 2004; Narula and Bellak, 2009). Inter-territorial relationships, then, are not necessarily competitive in nature but can also be cooperative in how firms use places in different ways (Taylor, 2010; Van Oort et al., 2010). Cities and regions can be complementary to the extent that they exploit different sources of competitive advantage and, hence, fulfil different economic roles within the urban system (Gordon, 1999; Taylor, 2010). ${ }^{3}$

Exploring the intensity of competition between regions over foreign investments fills an urgent need in the academic literature and in policy discourse. First, shifting the focus from measuring competitive advantage to measuring competition can contribute to the literature on territorial competition by providing a method to estimate the degree to which cities and regions are in competition, to identify clusters of competitive cities and regions, and to analyse the sources of territorial competition. Second, identifying the most important competitors of cities and regions provides a much better foundation for benchmarking (Bristow, 2005; Luque-Martínez and Muñoz-Leiva, 2005) as well as valuable input for local

\footnotetext{
1 At the same time, attracting many (high-level) investments can be a source of competitive advantage in that it generates a demonstration effect (Budd, 1998) as well as agglomeration externalities.

2 This is also reflected in the very uneven distribution of foreign investments across the world (see e.g., Wall et al., 2011).

3 This is also reflected in the work of Hewings, Sonis and associates (e.g., Hewings et al., 1996; Sonis and Hewings, 2000; Márquez and Hewings, 2003), who have shown that economic growth in one place does not necessarily obstruct but can also stimulate growth in other places.
} 
and regional policymakers. For example, having identified the most important competitors of a particular city or region, it becomes easier for government officials to recognise which aspects of territorial competitive advantage should be improved to increase the likelihood of attracting foreign investments. Hence, a good understanding of the competition and complementarities in urban systems clears the path to more goal-directed and effective strategic planning and policy-making with regard to territorial competitive advantage and long-term economic development strategies (Porter, 2000; Malecki, 2004).

Combining insights from international economics, international business, and urban systems literature, we develop an indicator to measure revealed competition between territories for investments. Focusing on the overlap of investment portfolios, it is argued that regions are in competition to the extent that they receive investments for the same functions, for the same sectors, and from similar parts of the world. In particular, we focus on the measurement of competition for greenfield investments (new investments as well as expansions) between NUTS-2 regions in the European Economic Area (EEA) ${ }^{4}$ and in Switzerland. European integration, which has facilitated the free movement of capital, goods, and workers and has gradually removed economic, social, and cultural differences between countries, has blurred national boundaries, resulting in the growth of territorial competition (e.g., Cheshire and Gordon, 1995; 1998; Gordon, 1999; Budd, 1998; Begg, 1999; Cheshire, 1999; Lever, 1999; Markusen and Nesse, 2007; Chien and Gordon, 2008). Today, MNCs increasingly perceive Europe as a relatively integrated territory rather than a collection of independent countries. Hence, European regions with similar characteristics situated in different countries are often perceived as closer substitutes than dissimilar regions in the same country (Basile et al., 2009). As location decisions involved in greenfield investments are not influenced by past capital instalments of the investee (unlike the acquisition of existing companies), these types of investments are useful for examining regional competition. ${ }^{5}$

The remainder of this paper is organised as follows: In Section 2, we focus on the conceptualisation of territorial competition for foreign investments within the context of MNC behaviour and the European enlargement. Section 3 introduces our measure of revealed competition between regions. Section 4 introduces our data. Section 5 provides an empirical analysis of competition between European regions, and section 6 contains the discussion and conclusion.

\footnotetext{
${ }^{4}$ Here, we define the EEA as the EU-25, Iceland, Norway, and Liechtenstein.

5 Cross-border greenfield investments constitute about $22 \%$ of all FDI in the world. The bulk of FDI takes the form of cross-border mergers and acquisitions (Brakman et al., 2006).
} 


\section{Competition for Greenfield Investments}

\subsection{Multinationals and Location Choice}

Foreign investments are long-range investments made by an MNC in a country other than the country in which the MNC has its home base. Based on Dunning's OLI paradigm (1993), firms decide to invest abroad when they have market power given by the ownership (O) of products or production processes, a location advantage $(\mathrm{L})$ in locating their plant in a foreign country rather than in their home country, and an advantage gained from internationalising (I) their foreign activities in fully owned subsidiaries rather than carrying them out through market transactions (trade) or networked relationships with other firms (licensing and franchising).

From the perspective of the internal organisation of the MNC, it is possible to distinguish between horizontal and vertical foreign investments (Barba Navaretti and Venables, 2004). Horizontal foreign investments involve investments in which a firm 'duplicates' abroad a number of its activities conducted in the home country. The main trade-off faced by firms engaging in this type of investment is between the increased sales, strategic advantage, and lower transport costs to be gained from operating abroad versus the forgone economies of scale at the plant level. Vertical foreign investments are investments in which a firm decides to geographically disperse its activities by function, whereby some of these functions are performed abroad. Here, the main trade-off is between the lower factor costs associated with investing abroad versus the increased trade costs and foregone economies of scale at the firm level.

Related to the OLI paradigm and the distinction between horizontal and vertical foreign investments, Dunning $(1993$; 1998) mentions four main motivations for firms to internationalise the production process and stress the location advantage: (1) access to natural resources (i.e., the natural resource-seeking motive); (2) access to new markets (i.e., the market-seeking motive); (3) the restructuring of production to reduce the costs of production related to labour, machinery and materials and increase efficiency (i.e., the efficiency-seeking motive); and (4) access to strategically related created assets (i.e., the strategic-asset-seeking motive).

The success of a region in attracting foreign investments largely depends on its relative attractiveness vis-à-vis other regions in terms of local resource availability. One can think 
here of an abundance of natural resources, large domestic markets, special tax breaks for MNCs, or a large pool of skilled workers. However, the relative importance of the different sources of competitive advantage varies across the motives of MNCs to invest abroad. A manufacturing plant predominantly needs low-wage modestly skilled labour and cheap land; sales and marketing offices call for a large domestic market in order to prosper; and high competence investments, such as $\mathrm{R} \& \mathrm{D}$ and headquarters functions, require high-level local resources that are often associated with agglomeration economies, clusters of related activities, and specialised skills (Narula and Bellak, 2009). Hence, MNCs with different motives to invest abroad will tend to focus on different location characteristics.

Along these lines, it can be argued that MNCs are constrained in their location choice by local resource availability, and not all regions are suitable for all types of investments because they lack the appropriate specialised location advantages. (Raines, 2003; Mataloni Jr., 2010). Especially for investments in knowledge-intensive sectors and R\&D and headquarters functions, the number of potential locations is limited given the very specific location requirements with respect to human capital. As indicated by Phelps et al. (1998), Gordon (1999) and Raines (2004), territorial competition would then also be most prevalent for the more standardized investments such as production plants.

In this light, Narula and Bellak (2009) and McCann (2011) have indicated that there exists a clear hierarchy of foreign activities in Europe, with the most advanced economies hosting the highest value-added activities, such as headquarters and R\&D functions. ${ }^{6}$ In contrast, foreign investments in Central and Eastern Europe are generally confined to lower value-added activities such as manufacturing plants and sales and marketing offices. Empirical support for this hierarchy is provided by Defever (2005) and Castellani and Pieri (2010), who show a concentration of foreign investments in R\&D and headquarter functions in the core regions of Western Europe, while logistics, production, sales and marketing units are more evenly spread across the continent. Similar differences can be observed when examining economic sectors instead of activities: foreign investments in knowledge-intensive manufacturing and services are more spatially concentrated than their less knowledgeintensive counterparts (Castellani and Pieri, 2010). The wider distribution of the less knowledge-intensive investments suggests a higher degree of territorial competition for these types of investment projects (Raines, 2003).

\subsection{Territorial Competition for Foreign Investments}


The majority of all potential locations in the world are not even considered by MNCs that aim to set up a subsidiary. This selectiveness of MNCs has important implications for territorial competition. Within the economic geography and regional science literature, territorial competition refers to "the actions of economics agents that are taken to enhance the standard of living in their own territories, such as regions, cities, or countries" (Poot, 2000, p. 205). Accordingly, it is not the regions that are in competition, but groups representing territorially based economic interests (Gordon and Cheshire, 1998). In particular, local and regional government officials engage in competitive activity because of electoral pressures to create jobs and safeguard business interests. In addition, officials often wish to be perceived as proactive in stimulating local and regional economic development (Turok, 2004; Markusen and Nesse, 2007). In recent years, the focus on territorial competition has grown along with an emphasis on attracting foreign investments (Lovering, 2003), where foreign investments are seen as both an instrument and an indication of territorial competitiveness. 'Competitive' territories attract more foreign investments, while foreign investments are thought to increase the competitive advantage of territories by creating new employment and bringing new knowledge and technologies to a region. ${ }^{7}$

In principle, regions compete to have the best locational endowments (Budd, 1998). However, there are many different policies to increase territorial competitiveness, ranging from incentive-based (tax benefits and subsidies) and rules-based (regulation) to capacity building policies related to improving the quality of place (Tewdwr-Jones and Phelps, 2000; Globerman and Chen, 2010). As indicated by Raines (2003) and Turok (2004), the most recent initiatives of authorities to attract foreign investments involve the augmentation and exploitation of regional assets related to specialised labour pools, university research, and even lifestyle and culture (Turok, 2004). These initiatives not only include capacity-building policies aimed at boosting long-run productivity, but also the selective attraction of inward investments using incentives and a marketing focus that emphasise and reinforce the distinctive strengths of a territory (Raines, 2003). In other words, local and regional policies tend to focus on enhancing the 'stickiness' of places (cf. Markusen, 1996). With respect to foreign investments, the aim is not only to attract high value-added investments, but also to avoid the relocation of firms and attract re-investments by MNCs already present in the region.

\footnotetext{
6 The development of such pattern was already predicted by Hymer (1970)

7 Nevertheless, most local and regional development policies are not specifically targeted at attracting foreign investments and maintaining MNC establishments, but at stimulating the business climate in general (Budd, 1998; Malecki, 2004; Turok, 2004).
} 
By developing a distinctive competitive advantage and targeting specific investments, authorities also try to avoid vulnerability and intensive territorial competition by creating a 'market niche'. Investments requiring high asset specificity especially are closely linked to particular locations (Phelps and Raines, 2003). This focus on the distinctiveness of regions echoes a sector- and function-based response to territorial competition (Raines, 2003), in which regions improve and exploit the characteristics that distinguish them from other regions (Begg, 1999). Such acquisition strategy for inward investments linked to a functional and sectoral focus for aspects of regional development also has clear attractiveness for the organisation of marketing around coherent descriptions of a region's competitive advantage (Raines, 2003). Thus, officials also increasingly realise that the nature of a particular investment limits the number of locations that can satisfy its criteria, and a region can best attract investments that complement their economic structure. First, it will require less effort from regions to attract these kinds of investments. Given that MNCs match corporate assets and locational requirements, it is important to target those investments for which the region is part of the consideration set of MNCs. Second, it can be expected that MNC establishments that are better embedded in the regional economic structure are less likely to relocate and more likely to receive reinvestments at a later stage.

These factors do not mean that all differentiation and discrimination policies are equally well founded, as some sectors and functions are clearly preferred over others by authorities. Today, biotechnology, software, and financial and business services are popular targets, while labour-intensive and less knowledge-intensive services tend to be neglected. Acquisition strategies based on groundless mimicry of successful regions, such as Silicon Valley and Cambridge, are also still commonly practiced in local and regional development policies and place marketing (Malecki, 2004; Turok 2004; 2009). Turok (2009) rightfully questions the use of such wasteful policies by less well-endowed regions. In fact, it is unrealistic to expect that every territory can become a financial centre or a leading knowledge-driven economy. Also, given the specific location requirements of an $\mathrm{MNC}$, the opportunities for attracting high-quality investments are extremely limited for those regions. Not only is such strategy a waste of time and money, but it also under-utilises the assets present in a region.

Along these lines, competition based on low taxes and low-wage labour has not disappeared. Regions that lack high-skilled labour and a sophisticated economic base are often desperate to attract low value-added foreign investments, such as sales and marketing 
offices and production-based units (Malecki, 2004). As these relatively standardised investments do not require specific location factors and because MNCs can play off governments against each other, incentive-based competition is expected be fiercest for these types of investment (Raines, 2003).

However, the European Union has always tried to avoid such a 'race-to-the-bottom' by banning most subsidies to business for plant locations (Cheshire and Gordon, 1998; Markusen and Nesse, 2007), where only some underdeveloped countries are allowed to attract foreign investments using incentive-based policies. However, as indicated by Markusen and Nesse (2007), this regulatory scheme of the European Union does not extend to local and regional governments' use of their own resources or taxing policies to attract MNCs, except when national authorities compensate them for such inducements. Although such local and regional discretionary powers are at present relatively limited, it can be expected that they will increase in the future when European countries transfer economic development policies to sub-national levels of government.

\subsection{MNCs, Territorial Competition and Territorial Complementarities}

However, there can also be competitive tensions between subsidiaries of the same MNC (Phelps and Fuller, 2000; Phelps and Raines, 2003). As indicated by Phelps and Fuller (2000), subsidiaries can have autonomous corporate agendas and, hence, within the same MNC subsidiaries compete for repeat investments. Phelps and Fuller (2000) address intra-MNC competitive processes that are initiated by changing divisions of labour within the MNC in which subsidiaries can win or lose responsibilities. Indeed, such competition can be fierce in light of corporate restructuring, in which some subsidiaries must be discontinued, whereas other subsidiaries receive reinvestments and can expand. Therefore, territorial competition can be perceived as an unintended consequence of the goal-directed behaviour of firm establishments, in which governments become involved because foreign activity is important for territorial competitive advantage (Raines, 2003). Hence, territories compete because subsidiaries of the same MNC compete.

Nevertheless, this dynamic provides an incomplete description of the relationships between territories. Relationships between MNC subsidiaries can be complementary in that they fulfil different functions within the organisation. In this respect, Beaverstock (2001) and Taylor (2010) highlight an example of financial and other services providers in Frankfurt and 
London. By means of interviews with practitioners in firms that had offices in both cities, it became clear that the relationship between Frankfurt and London was mainly complementary: London served as a strategic centre for global business, while the Frankfurt office was mainly serving the European market. Thus, both cities are used by the same MNC, but in different ways. Hence, territories are not necessarily in competition, as they can have distinct competitive advantages used by firms for different reasons and, hence, can cooperate on the basis of mutuality (Gordon, 1999; Taylor, 2010; Van Oort et al., 2010). In this respect, complementarities are present between differently specialised regions that are linked through input-output relations (Scott and Storper, 2007). ${ }^{8}$

\subsection{MNCs, European Integration and Territorial Competition}

The viewpoint of the existence of investments between similar subsidiaries/regions is more prevalent within an integrated market. In international economics, attention has been paid to horizontal foreign investments, in which MNCs build to overcome high trade costs. In this situation, there is a complementary relationship between similar subsidiaries within the same MNC. Although these subsidiaries conduct the same economic activities, they serve different markets. Thus, territorial competition between regions with similar locational endowments is also more opaque.

However, within the light of globalisation and European integration, vertical investments gain significance due to a reduction of trade costs at the expense of horizontal investments. The removal of tariff and non-tariff barriers to trade and the free movement of capital and labour in the European Union in combination with decreasing transportation costs and improved information and communication technologies is generating a European economy in which MNCs can concentrate particular activities of their value chain in one single location. According to Cheshire and Gordon (1995, p. 111), “companies are increasingly restructuring themselves to serve the European market as a whole rather than a set of national markets. They eliminate national headquarters and have just a European headquarters; they have European-wide marketing strategies; they streamline their production range and concentrate their production".

Horizontal foreign investments can be considered a substitute for trade (Barba Navaretti and Venables, 2004), where MNCs can overcome trade barriers by setting up foreign subsidiaries to serve foreign markets. By the creation of the Single Market, such trade barriers

\footnotetext{
8 For example, a region specialized in financial services, can provide these services to a territory specialized in manufacturing, and vice
} 
have been diminished within the Europe, thus discouraging horizontal foreign investments between countries within the European Union. Due to market enlargement, foreign investments from outside the European Union have increased, but this often takes the form of export-platform foreign investments in which the whole of the European Union is served by a non-European MNC from one single location (Neary, 2002). At the same time, the decrease of barriers to trade has stimulated investments of the vertical variety, which is complementary to trade. Due to decreased investment and trade costs, MNCs could no longer easily take advantage of differences in factor prices between regions, resulting in a slicing up of the value chain.

These developments not only occur in manufacturing industries but increasingly so in services, where trade costs have traditionally been higher due to intensive face-to-face interaction (Glaeser and Kohlhase, 2004; McCann, 2008). However, due to technical advancements, such as the acceptance of English as the lingua franca and the liberalisation of trade in services, the fragmentation of the commodity chain is also becoming a more common practice in services (Deardoff, 2001; Head et al., 2009). Hence, it is expected that territorial competition for services functions will further increase in the near future.

\subsection{Towards Measurement of Competition for Greenfield Investments}

From the above review, it has become clear that the relationship between regions is both of competitive and cooperative nature. Regions that have different specializations and orientations are likely to be active in different segments in the market for investments. Based on the tension between competition and complementary relations between territories, three conditions for the existence of territorial competition can be identified: (1) sectoral market overlap, (2) functional market overlap, and (3) geographical market overlap. Accordingly, competition for investments is conceptualised as the lack of inter-regional differentiation, in which regions have overlapping segments. In the 'market for investments', in which territories supply and MNCs demand locations, territorial competition would be high when territories receive investments for the same functions and sectors from similar parts of the world. Likewise, regions would be complementary when territories receive investments for different functions and sectors from different parts of the world. In the next section, we will introduce a measure to quantify the degree of competition for investments between regions that takes in these three conditions. 


\section{Quantifying Territorial Competition for Investments}

The degree of territorial competition (and complementarities) over attracting foreign investments can be assessed by examining the overlap in investment portfolios. The investment portfolio of a territory reveals the competitive advantage for foreign investments in that territory (UNCTAD, 2001). Hence, the investment portfolio of a territory displays information about the attractiveness of territories for particular foreign investments. In this manner, it is acknowledged that MNCs can use territories in different ways, and territories that have similar locational assets function as substitutes. Accordingly, relations between territories with similar investment portfolios are competitive, while relations between territories that have different investment portfolios are cooperative. Based on our theoretical framework, three conditions for the existence of competition between regions for investments have been identified: (1) sectoral similarity in investments, (2) functional similarity, and (3) geographical similarity. Accordingly, the revealed competition between territories is high when they receive investments for the same sectors and functions from similar parts of the world.

Although relatively absent in the study of foreign investments, similarity indices have been extensively used in the social sciences to assess revealed competition between members of a given population based on niche overlap. In its original connotation, a niche of species is defined as the set of environmental states in which a species thrives, and it typically consists of the resources on which a species depends for its survival, such as its natural habitat from which it collects food. From the 1970s onwards, the concept of niche has been introduced in the social sciences, most notably in organisation studies (Hannan and Freeman, 1977; Podolny et al., 1996) and social network analysis (McPherson, 1983; Burt and Talmud, 1993).

Likewise, in international economics, the Finger-Kreinin index (Finger and Kreinin, 1979) has been used to assess the competitive threat one country poses the other (see e.g., Jenkins, 2008; Duboz and Le Gallo, 2011). This measure uses a relative Manhattan index-based indicator to measure the similarity in export structure between two countries. Applied to the context of foreign investments, the degree of similarity in the investment portfolio structure of regions $i$ and $j$ can be expressed as the overlapping of market segments $h$ between $i$ and $j$. A market segment is here defined as a group of investments that share the same (1) sector, (2) function, and (3) world region of origin. Hence, foreign investments in low-tech manufacturing production plants originating from Asia are treated as a different segment from that consisting of investments in financial services headquarters originating from North 
America. More formally, the similarity $S$ between the investment portfolios of regions $i$ and $j$ can be expressed as follows:

$$
s_{i j}=\sum_{h=1} \min \left(x_{i h}, x_{j h}\right)
$$

in which $x_{i n}$ is the share of the market segment $h$ in region $i$ 's portfolio of investments, and $x_{j h}$ is the share of the market segment $h$ in region $j$ 's portfolio of investments. If the value of the index equals zero, the markets of regions $i$ and $j$ are completely different, and the intensity of competition between the two regions would be at a minimum. In other words, the relationship between the regions can be regarded as fully complementary. If the value of the index equals one, the markets of regions $i$ and $j$ completely overlap, and the intensity of competition between the two regions would be at a maximum.

However, a serious drawback of the relative Manhattan distance is that it does not take into account the absolute number of investments, and accordingly, it only reflects the degree of competition well when the sizes of the regions are more or less equal (Jenkins, 2008). By focusing on portfolio structure instead of the number of investments, the index implies that the competitive threat posed by region A to region B is the same as the competitive threat posed by region $\mathrm{B}$ to region $\mathrm{A}$, which only works when both regions are relatively similar in (economic) size. The illogicality of this measurement also becomes clear when, for example, region A is London and region B is Malta (see also Jenkins, 2008). From the perspective of a region like Malta that is concerned about the competition it faces from a region such as London, what is important is the proportion of its investment portfolio for which it has to compete with London as a location of residence. In other words, the share of these investments in the portfolio of London does not matter as such. As such, territorial competition should be based on an absolute advantage principle and not on a comparative advantage principle (Camagni, 2002). Accordingly, we use a weighted similarity index (for a similar approach, see Thissen et al., 2012) to assess the competitive threat regions pose to one another. For any investment type, a region will experience fierce competition from a competitor region if (1) the investments constitute an important part of the region's investment portfolio and (2) the level of these investments is at the same level as that of its competitor region. Formally, the competitive threat $C$ region $j$ poses to $i$ can be expressed as follows: 


$$
c_{j i}-\Sigma_{k=1} s_{i h}\left(1-\frac{\left|x_{i n}-x_{j h}\right|}{\left(x_{i h}+x_{j h}\right)}\right)
$$

In which $s_{i n}$ is the share of market segment $h$ (sector by function by world region) in region $i$ 's portfolio of investments, $X_{i h}$ is the number of investments region $i$ receives in market segment $h$, and $X_{j h}$ is the number of investments region $j$ receives in market segment $h$. Like the relative Manhattan index, the weighted similarity index ranges from 0 (complementary relationship) to 1 (competitive relationship). The proposed index is asymmetric in that the territorial competition region $\mathrm{A}$ receives from region $\mathrm{B}$ does not necessarily have to be the same as the territorial competition region $\mathrm{B}$ receives from region $\mathrm{A}$.

However, a weakness of this revealed competition measure is that outcomes are, at least to some extent, dependent on the definition of the different market segments (see also Kellmann and Schroder, 1983). Here, we have considered a classification that includes neither too many nor too few separate segments, while taking into account theoretical considerations of plausibility and functionality. Based on our data (described in the next section), the market segments are delineated by 9 broad sectors, 7 functions ${ }^{9}$, and 7 world regions of origin ${ }^{10}$. The result is $441(9 * 7 * 7)$ potential market segments. In 315 of these 441 potential segments, at least 1 investment was made, while in 262 segments more than 1 investment was made

\section{Data}

To analyse the degree of competition between European regions, we make use of the Financial Times fDI Markets database, a detailed register of cross-border investments that are made worldwide. The greenfield projects that are covered include new investments and expansions, but not mergers, acquisitions, or joint ventures. More specifically, we focus on investment projects in 264 NUTS-2 regions ${ }^{11}$ across 29 European countries (EU-25 as well as Iceland, Liechtenstein, Norway and Switzerland) for the period January 2003 - October 2011. These data are recorded on the basis of formal announcements by the media, financial information providers, industry organisations, and market and publication companies. All

\footnotetext{
9 The taxonomy of sectors and functions is based on the classification presented in the work of Van Oort (2004), where the subsectors within the broad sectors have related production processes and locational demands. A similar taxonomy was for the different functions (see also Castellani and Pieri, 2010). The categorization of countries in five world regions (Western Europe, Rest of Europe, North America, AsiaPacific and Rest of the World) is based on the idea that motivations for intra-bloc investments (investments form the EU into the EU) are substantially different from inter-bloc investments. Likewise, motivations for MNCs from developing countries to invest in Europe are substantially different from those of developing countries.

10 Latin America, Africa and the Middle East are here included as seperate categories.
} 
projects are cross-referenced with multiple sources, and 90\% of all investment projects are validated with company sources. No official minimum investment size exists, although investment projects creating less than 10 full-time jobs or involving a total investment of less than $\$ 1$ million are relatively uncommon. At present, the fDI Markets database is the leading source of FDI project data for the large FDI statistics organizations, such as the United Nations Conference on Trade and Development (UNCTAD), Economist Intelligence Unit (EIU) and World Bank. When we compare the distribution of inward investments across the NUTS-1 regions in the fDi Markets database with the distribution of inward investments in the Ernst \& Young's European Investment Monitor for the period 2003-2008 (Brienen et al., 2010), we find a correlation of 0.94. Likewise, the distribution of investments across sectors and functions in the two datasets is comparable.

Overall, the database contains 27,550 investments made in Europe by 12,240 MNCs. Approximately one third of these investments are made by the top 500 firms. For 26,995 $(98.0 \%)$ of these investments, detailed information was available regarding the NUTS-2 region in which the investment was made. Figures 1-3 show the distribution of these investments in Europe across broad sectors, economic functions, and world region of origin (see Appendix A). Figure 1 shows that most investments are relatively equally spread across sectors. Most investments were made in the ICT and telecommunications sectors (20\%) and the low-tech manufacturing (16\%) sector. However, when we examine the distribution of investments across economic functions (i.e., the stage or activity within the value chain of the firm) in Figure 2, we see a strong concentration of investments in production plants (32\%) and sales and marketing offices (27\%). Headquarters and R\&D units are less targeted functions. Most investments (53\%) made by MNCs are based in Western Europe (Figure 3).

\section{INSERT FIGURE 1-3 ABOUT HERE}

Table 1 gives an indication of the spatial distribution of foreign investments in Europe by presenting the top 20 regions in Europe in terms of the number of inward investments they receive. Most foreign investments are targeted at Greater London (6.7\%) and the Ile-deFrance (4.4\%, Paris) region. Not surprisingly, this concentration mainly includes investments in business services, sales and marketing, and headquarters functions in the ICT and telecommunications, financial services, commercial services, and high-tech manufacturing

\footnotetext{
11 This excludes Andorra (AD00), Faeroe Islands (FO00) Greenland (GL00), Gibraltar (GI00), Guernsey (GG00), Isle of Man (IM00), Jersey (JE00) and Monaco (MC00). However, data for these territories is available upon request.
} 
sectors. In reality, most European top regions are overspecialised in attracting foreign investments in higher value-added sectors and functions. ${ }^{12}$ Nevertheless, there are also strong indications of the existence of complementarities among top European regions. For example, Ile-de-France (FR10, Paris) specialises in ICT and commercial services, and Rhône-Alpes (FR71, Lyon) specialises in high-tech manufacturing, medium-tech manufacturing, processing industries, and transport services. Along these lines, most region pairs are not completely competitive or complementary but are somewhere in between these two extremes.

\section{INSERT TABLE 1 ABOUT HERE}

\section{Structure of Territorial Competition}

\subsection{Competition across Sectors, Functions and World Region of Origin}

Revealed competition within market segments can be compared by dividing the sum of the weighted similarity index across region pairs and relevant market segments by the maximum possible overlap for the relevant segments. ${ }^{13}$ Table 2 shows the revealed competition between European regions for different types of investments by sector and function. From this table, it is clear that competition over investments in the low value-added sectors and functions is higher than across the high value-added sectors and functions. The competition for investments in low-tech manufacturing (0.35) and process industries $(0.34)$ is much higher than for investments in the services sectors. Likewise, the competition for investments in production (0.34) and logistics (0.27) is much higher than for headquarter functions $(0.10)$, which is consistent with the expectation that territorial competition is fiercest for those investments that do not require highly specific location factors and the observation that investments in the lower value-added segments are more equally distributed across European regions than investments in the higher value-added segments. Table 2 indicates that a larger share of regions receives at least 1 investment in lower value-added segments such as production plants, logistics, low-tech manufacturing, and process industries. In addition, investments in these lower value-added segments are less concentrated in only a few regions.

\section{INSERT TABLE 2 ABOUT HERE}

\footnotetext{
12 Most regions with a strong overspecialization in inward foreign investments in lower-value added sectors (e.g., low-tech manufacturing) and functions (e.g., production plants) can be found in peripheral Europe.

13 Typically, this is a situation in which the investments in the relevant segments are perfectly equally distributed across the regions. Hence, the maximum possible overlap is computed as the share of investments in the relevant market segments in the investments times the number of region pairs.
} 
In addition, competition for investments from Western Europe is much fiercer than competition for investments from other parts of the world. The latter are concentrated in only a few European regions. For example, Greater London receives only $2.9 \%$ of all investments from Western Europe. At the same time, it receives 12.1\% of all investments from North America, 9.1\% of all investments from the Asia-Pacific region, $8.9 \%$ of all investments from the rest of Europe, and $11.1 \%$ of all investments from the rest of the world. As indicated by Rugman and Verbeke (2005), the scope of most MNCs is continental and not global, and there are only a few truly global regions in the European urban network that link the other European regions to the rest of the world, including Greater London, Ile-de-France, and, to a lesser extent, the regions around Dublin (linked to North America); Madrid (linked to Northand Latin America); Frankfurt (linked to North America and Asia-Pacific); Munich (linked to North-America and Asia-Pacific); Amsterdam (linked to North-America); and Düsseldorf (linked to Asia-Pacific). ${ }^{14}$

Looking at the top 10 competitive market segments in Table 3, the competition appears to be fiercest for West-European and North-American (efficiency-seeking) investments in production units in the low- and medium-tech manufacturing industries. The lowest degree of competition can be found in the smallest market segments. However, there are also a considerable number of large market segments (consisting of more than 100 investments) in which the degree of territorial competition is relatively low (that is, an overlap of $<0.15$ ). As

shown in Table 4, this predominantly market- and strategic-asset-seeking investments in financial and other commercial services offices.

\section{INSERT TABLES 3 AND 4 ABOUT HERE}

\subsection{Revealed Competition between Regions}

The relationships between some regions are more competitive than the relationships between others. Table 5 shows the most important competitors of the Greater London (UKI) and Lower Silesia (PL51) regions as well as the regions to which Greater London and Lower Silesia pose a competitive threat. As indicated in Table 1, these regions have distinct specialisations in foreign investments. Whereas London ranks first in the number of inward investments in business services, financial services, and ICT and software, Lower Silesia 
ranks first in the number of inward investments in production plants. The relationship between Greater London and Lower Silesia is essentially complementary. Both the competitive threat that Lower Silesia poses to London (0.06) and the competitive threat that Greater London poses to Lower Silesia (0.250) can be considered to be very low.

From Table 5, it is clear that the main competitor regions of Greater London are not the same as the competitor regions of Lower Silesia. Whereas Greater London mainly faces competition from Ile-de-France (0.588), Dublin (0.367), and Madrid (0.366), Lower Silesia is mainly 'at war' with Western Slovakia (0.651), Catalonia (0.641), and Silesia (0.605). A similar observation can be made with respect to the regions to which Greater London and Lower Silesia pose a threat. Regions that face considerable competition from Greater London include both large regions with a similar investment portfolio (e.g., Ile-de-France and Communidad de Madrid) and small regions receiving only a small number of specific investments (e.g., Drenthe, Cantabria, Koblenz and West-Vlaanderen). Still, the relationships between regions are not necessarily competitive but can also be complementary. For example, Merseyside (UKD5), Essex (UKH3), Surrey, East and West Sussex (UKJ2), and Devon (UKK4) do not face a large competitive threat from London, having less than a one third overlap of their investment portfolio with Greater London's.

\section{INSERT TABLE 5 ABOUT HERE}

\subsection{The Gravity of Revealed Competition and Complementarities}

Distinctiveness in relation to complementary relationships between European regions can be analysed by using a gravity-type regression model. ${ }^{15}$ Following our theoretical discussion, it can be argued that similarity in locational endowments induces competition between regions, and dissimilarity in locational endowments generates complementarities between regions in attracting foreign investments. To explain the geography of competition and complementarities in the European regional network, we include variables that measure the absolute value (modulus) of the difference in location characteristics between regions. These variables can be linked to the main motivations of MNCs to invest in foreign regions (see Section 2.1). More specifically, we take into consideration variables related to the attractiveness of locations and that are often used in the analysis of the location choice of

\footnotetext{
14 On a similar note, most foreign investments originating from Eastern Europe are still targeted at East European countries. For example, over $50 \%$ of all Latvian foreign investments in European countries are targeted at Estonia and Lithuania.
} 
MNCs (see, e.g., Head and Mayer, 2004; Defever, 2005; Basile et al., 2008; 2009; Brienen et al., 2010), as they can be linked to the different motivations of firms to invest abroad.

Our dependent variable is the log of the weighted similarity index for the period 20032010, as presented in equation 2. For natural resource-seeking motives, we include employment in mining and quarrying as a share of total employment. For market-seeking motives, we include market size, GDP per capita, and accessibility. In line with the marketseeking hypothesis, larger regions in terms of Gross Value Added tend to be more attractive to MNCs because MNCs are thereby able to serve a larger market. GDP per capita measures the purchasing power in the region, while accessibility by air and accessibility by road and rail are included to capture the quality of the infrastructure, as it can be expected that regions that are better accessible will receive more investments. For efficiency-seeking motives, we include wage per hour, social charges rate, and corporate taxes as covariates. The social charges rate is provided by the Ernst \& Young International Human Capital database and is calculated as the non-wage labour costs (payroll taxes, social security contributions, recruitment costs) as a percentage of the total labour costs (Brienen et al., 2010). The costs of capital are captured by the corporate tax rate and are measured as the statutory tax percentage rate at and obtained from the Ernst \& Young International Tax database (also see Brienen et al., 2010). Both the social charges rate and the tax rate are measured at the country level. Finally, strategic asset-seeking motives are measured by the $R \& D$ expenditures as $\%$ of GDP. All variables are measured for the year 2007. Finally, we include distance and similar country dummies to account for unobserved similarities between countries located in close proximity to each other or falling under the same institutional regime.

Table 6 provides an overview and description of the variables included in the model. We estimate a two-way fixed effects model, including region fixed effects. Such a doubly constrained gravity model ensures that the observed degree of competition equates the expected degree of competition and yields consistent parameter estimates for the variables of interest (Fotheringham and O'Kelly, 1989; Bröcker and Rohweder, 1990). In addition, it controls for omitted variable bias and for the fact that the competitive threat that, for example, Greater London poses to other regions is generally greater than the competitive threat that small regions such as Drenthe, Cantabria, Koblenz and West-Vlaanderen pose to other regions. In a cross-sectional setting, a fixed effects specification implies the inclusion of region-specific 'exporter' (i.e., regions that pose a competitive threat) and 'importer' (i.e.,

15 For the use of gravity models (spatial interaction models) in economics and geography, see for example Fotheringham and O' Kelley (1989) and Burger et al. (2009) 
regions that face competition) dummy variables. Sufficient information was available for 245 of the 264 regions, yielding $57840\left(245^{*} 244\right)$ observations in our regression model. ${ }^{16}$ The VIF statistics indicated no multicollinearity problems. ${ }^{17}$

\section{INSERT TABLE 6 ABOUT HERE}

Table 7 show the results of the estimation of the log-normal model using the White estimator to obtain robust standard errors. ${ }^{18}$ Overall, it can be inferred that, consistent with the theory, most variables have the expected sign and are highly significant. Regions that differ in natural resource abundance, income levels, wage costs, accessibility, population density, patent intensity, and population with a university degree pose a relatively small competitive threat to one another. For example, if the difference in wage per hour between two regions doubles, the degree of revealed competition between regions drops by $9 \%$, holding everything else constant. Likewise, an increase in the difference in the share of the population with a university degree by 1 percentage point increases the degree of revealed competition between regions by 0.25 percentage points. We find a negative and significant effect of physical distance and the country dissimilarity dummy on the degree of revealed competition between regions, holding everything else constant (see Model 2). ${ }^{19}$ Although this can signify that the European market is not (yet) an integrated territory, the significance of the distance and country dissimilarity variables might also reflect unobserved differences between regions, where regions located in the same country and in close proximity to each other share locational similarities not accounted for in the model.

\section{INSERT TABLE 7 ABOUT HERE}

\subsection{Competitive vs. Cooperative Regions}

Some regions face a higher threat of competition than others. The average competitive threat region $i$ faces from other regions $j$ can be estimated by summing the revealed competition coefficient (equation 2) for $i$ over all competitor regions $j$ and dividing this value by the number of regions in the sample. Likewise, the competitive threat region $j$ poses to other

\footnotetext{
16 In particular, information was missing for the EFTA countries (Iceland, Liechtenstein, Norway, and Switzerland) and some extraterritorial regions belonging to Spain and Portugal (Azores, Madeira, Ceuta, Melilla).

17 VIF statistics are available upon request.

18 A Poisson regression (available on request) provided similar results.

19 As there was considerable multicollinearity between the tax rate and country dissimilarity dummy we ran separate regressions.
} 
regions $i$ can be estimated by summing the revealed competition coefficient for $j$ over all competitor regions $i$. As the revealed competition measure is asymmetric, the average competitive threat a region poses does not have to be the same as the average competitive threat a region faces.

Table 8 provides an indication of which regions pose the largest (smallest) threat to all other regions and which regions face the largest (smallest) competition from all other regions. From the table, it can be observed that Greater London, Paris and Dublin, which are sufficiently large and distinctive, face the smallest average competitive threat from all other regions. In contrast, less populous, peripheral regions such as regions in Central and North Greece and the Greek isles appear to encounter greater difficulties because they face a relatively large competitive threat from other regions. At the same time, most of these regions do not pose a large threat to other regions (correlation $=-0.50$ ). The regions that pose the largest competitive threat to other regions include some usual suspects (Communidad de Madrid, Lombardia, and Oberbayern) as well as some less obvious candidates (Eastern Scotland, South Western Scotland, Rhône-Alpes, and Andalucía). The latter group mainly consists of large regions receiving numerous foreign investments in medium to highly competitive market segments, including the high-tech manufacturing and processing industries. A better understanding of the competitive threat a region poses or faces can be obtained by means of a linear regression analysis on the average competitive threat using the location factors introduced in the previous subsection (3) as explanatory variables.

\section{INSERT TABLE 8 ABOUT HERE}

We use the logarithm of the competitive threat a region poses or faces as dependent variables. Table 9 shows the results of the estimation of the log-normal model. The regression results show that those regions that stand out in terms of a large market size, good accessibility by air, a skilled labour force, low taxes, and low wages pose the largest competitive threat to other European regions (Model 3). ${ }^{20}$ None of the European regions possesses all these qualities, but it at least provides an explanation for the competitive threat that the abovementioned second-order West European regions (Eastern Scotland, Southwestern Scotland, Rhône-Alpes, and Andalucía) pose to other regions. Accessibility by road, population density and rail and natural resource abundance play a less important role. There is a positive effect of

\footnotetext{
${ }^{20}$ In these regressions, GDP per capita had to be omitted due to a high degree of collinearity with the wage variable.
} 
$\mathrm{R} \& \mathrm{D}$ expenditures on the amount of competition a region poses to other regions, but there is much uncertainty about the true value of this parameter. Examining the competitive threat that regions face (Model 4), it is shown that large and densely populated regions face a relatively smaller competitive threat. In addition, skilled labour force and low tax rate reduce the average competitive threat a region faces from all regions. A similar picture is obtained when conducting a regression analysis on the degree to which a region poses a threat to other regions relative to the degree to which a region faces a competitive threat from other regions (Model 5). These results convincingly show that there are indeed two ways to outcompete other regions in attracting investments: having capacity-building policies that stimulate the knowledge base of the regions and incentive-based policies that reduce the cost of capital and labour. Accordingly, cities and regions can focus on capacity-building policies that are associated with promoting productivity and economic growth more broadly, and hence increase the attractiveness of the location, or policies such as subsidies and tax breaks that specifically target MNCs (see also Globerman and Chen, 2010).

\section{INSERT TABLE 9 ABOUT HERE}

\section{Conclusions and Discussion}

This paper introduces an indicator to measure the intensity of competition between pairs of regions, which can be considered the most fine-grained level at which competition can be measured. Regions are considered to be in competition when they have overlapping investment portfolios in terms of (1) sectors in which it is invested, (2) functions in which it is invested, and (3) geographical origin of the investment. Using the revealed competition measure as a building block, it is possible to identify competitive market segments, derive the competitive threat a region faces from other regions, the competitive threat regions pose to other regions, and the most important market segments in which regions compete.

In this paper, we applied the revealed competition measure to territorial competition for foreign investments in Europe using data on greenfield investments. In light of European integration and globalisation, it is often argued that territorial competition will increase as the free movement of capital, goods and workers and the removal of economic, social and cultural barriers have made national boundaries disappear. Accordingly, MNCs often perceive European regions with similar characteristics situated in different countries as closer substitutes than dissimilar regions in the same country. This perception is, at least partly, 
reflected in our empirical assessment, which shows that European regions with similar locational endowments pose a fiercer competitive threat to one another than regions with different locational endowments. However, some regions are more competitive than others in that they pose a relatively higher competitive threat to other regions and at the same time face a relatively limited competitive threat from other regions. Typically, these are large, accessible regions with a skilled labour force and/or low costs of capital and labour. Regional giants such as Greater London and Ile-de-France battle against each other, but they face a low competitive threat from other regions in that they are simultaneously large and sufficiently distinctive. These regions specialise in attracting high value-added investments in financial and business services. Perhaps paradoxically, territorial and regional competition for investments appears fiercest for those foreign investments that have the lowest value added (i.e., efficiency-seeking investments in production plants in low- and medium-tech manufacturing) and that no region really prefers. However, when the location requirements for investments are minimal, the number of regions that are included in the consideration set of a MNC is relatively large. As a MNC can choose from a wide range of locations, it can play governments against each other by asking for tax cuts or subsidies. Hence, a high degree of competition in this market as reflected by the revealed competition measure would also make sense from a substantive point of view.

There are, however, some limitations with regard to the measurement of the revealed competition indicator, which require further investigation. Most importantly, results can be dependent on the size and relative size of the pairs of regions confronted. A large region experiences less threat from a small region than vice versa. This is acceptable in economic terms as long as regions are similarly defined. However, NUTS-2 regions in Belgium, Germany, and the Netherlands are more similar to NUTS-3 regions in France, Italy and Poland than to their respective NUTS-2 regions. A solution here could be to follow the OECD mixed NUTS 1-2 (TL1) or NUTS 2-3 (TL2) delimitations. At any case, future research should address the sensitivity of results to this Modifiable Areal Unit Problem (Openshaw and Taylor, 1979). A similar case can be made with regard to the definition of the different segments.

Finally, we focused on the number of investments and did not take in the size of the investments in terms of the amount of capital that is invested or the number of jobs that are created due to data availability. To the casual observer, the most intense competition between European regions in recent decades was in the 1990s when a series of very large investment projects in manufacturing was being offered up as Japanese, Korean, and German companies 
internationalised (Phelps et al., 1998; Phelps and Tewdwr-Jones, 2001). On the one hand, our research also indicates that competition is fiercest for these large numbers of jobs in production plants since investments in these segments (low-tech manufacturing, process industries, and production plants) are relatively footloose in that they do not have very specific location requirements. On the other hand, it can be argued that the intensity of competition for the investment projects also varies according to the size of investment and this deserves attention in future research.

The revealed competition measure presented in this paper is not meant to replace other accounts of territorial competitiveness and territorial competition but rather should be perceived as complementary. First, the rankings of cities and regions may still be useful as indicators of territorial competitiveness, but it is important to recognise that not all relations between territories are of a competitive nature, and therefore, not all cities and regions should be compared by putting them on the same ranking list. Second, having identified the most important competitor region and its competitive advantage in attracting foreign investments, it becomes easier for regional planners and marketers to recognise the aspects of competitive advantage that should be addressed to increase the likelihood of attracting foreign investments, which facilitates more goal-directed and effective strategic planning and policy making with regards to territorial competitiveness. In this respect, regional authorities also increasingly recognise that foreign investments are not, by definition, a catalyst for economic growth and that it is best to attract investments that complement the economic structure of the region to promote sustainable development. It is not easier to attract such investments, but the probability that an MNC will become embedded in the regional economy (e.g., local labour markets, input-output structures) and not relocate will also be increased.

In addition to indicating the intensity of territorial competition, future research can utilise the revealed competition measure by linking territorial competition to territorial performance. Other aspects of in inter-regional competition based on trade (see Thissen et al., 2012) should also be investigated. Accordingly, the focus shifts from territorial competition as a dependent variable ("causes of urban competition") to territorial competition as an independent variable (“consequences of urban competition"). Naturally, new questions arise. How does territorial competition affect territorial performance? Are cities and regions that face less competitive threat from other regions more likely to grow and strengthen their position within the urban system? Is it is through increasing competition over time and space that places can become specialized in particular activities, whereupon they are regarded as complementary and 
therefore seeming to act in a cooperative manner? Similarly, a research program in which interactions between the local and the global take centre stage unfolds.

\section{Acknowledgements}

We would like to thank two anonymous reviewers for their comments on an earlier draft of this paper. All errors remain the authors'.

\section{References}

Aharoni, Y. (1966) The Foreign Investment Decision Process. Cambridge, MA: Harvard University Press.

Barba Navaretti and Venables (2004) Multinational Firms in the World Economy. Princeton, NJ: Princeton University Press.Basile, R., Castellani, D., Zanfei, A. (2008) Location choices of multinational firms in Europe: the role of EU cohesion policy. Journal of International Economics, 74: 328-340.

Basile, R., Castellani, D., Zanfei, A. (2009) National boundaries and the location of multinational firms in Europe. Papers in Regional Science, 88: 733-748.

Beaverstock, J.V., Hoyler, M., Pain, K., Taylor, P.J. (2001) Comparing London and Frankfurt as World Cities: a Relational Study of Contemporary Urban Change. London: AngloGerman Foundation.

Begg, I. (1999). Cities and competitiveness. Urban Studies, 36: 795-809.

Brienen, M.J., Burger, M.J., Van Oort, F.G. (2010) The geography of Chinese and Indian greenfield investments in Europe. Eurasian Geography and Economics, 51: 254-273.

Bristow, G. (2005) Everyone's a 'winner': problematising the discourse of regional competitiveness. Journal of Economic Geography, 5: 285-304.

Bröcker, J., Rohweder, H.C. (1990) Barriers to international trade: methods of measurement and empirical evidence. The Annals of Regional Science, 24: 289-305.

Buckley, P.J., Devinney, T.M., Louviere, J.J. (2007) Do managers behave the theory suggests? A choice-theoretic examination of foreign direct investment location decisionmaking. Journal of International Business Studies, 38: 1069-1094.

Budd, L. (1998) Territorial competition and globalization: Scylla and Charybdis of European cities. Urban Studies, 35: 663-685. 
Burger, M.J., Van Oort, F.G. and Linders, G.J.M. (2009) On the specification of the gravity model of trade: zeros, excess zeros and zero-inflated estimation. Spatial Economic Analysis, 4: 167-190.

Burt, R.S., Talmud, I. (1993) Market niche. Social Networks, 15: 133-149.

Camagni, R. (2002) On the concept of territorial competitiveness: sound or misleading? Urban Studies, 13: 2395-2412.Castellani, D., Pieri, F. (2010) The effect of foreign investments on European regional productivity. Working paper. ISSN 1825-0211.

Cheshire, P. (1999) Cities in competition: articulating the gains from integration. Urban Studies, 36: 843-864.

Cheshire, P.C., Gordon, I.R. (1995) European integration: the logic of territorial competiton and Europe's urban system. In J. Brotchie, M. Batty, E. Blakely, P. Hall, P. Newton, Cities in Competition: Productive and Sustainable Cities for the $21^{\text {st }}$ Century. Melbourne: Longman, pp. 108-126.

Cheshire, P.C., Gordon, I.R. (1998) Territorial competition: some lessons for policy. The Annals of Regional Science, 32: 321-346.

Chien, S.S., Gordon, I. (2008) Territorial competition in China and the West. Regional Studies, 42: 31-49.

Deardoff (2001) International provision of trade services, trade and fragmentation. Review of International Economics, 9: 233-248. Defever, F. (2005) Functional fragmentation and the location of multinationals in the enlarged Europe. Regional Science and Urban Economics, 36: 658-677.

Duboz, M.L., Le Gallo, J. (2011) Are EU-15 and CEEC agricultural exports in competition? Evidence for 1995-2005. Economics Bulletin, 31: 146-154.

Dunning, J.H. (1993) Multinational Enterprises in the Global Economy. Wokingham: Addison-Wesley.

Dunning, J.H. (1998) Location and the multinational enterprise: a neglected factor? Journal of International Business Studies, 29: 45-66.

Dunning, J.H., Narula, R. (2004) Multinational and Industrial Competitiveness: A New Agenda. Cheltenham: Edward Elgar.

Finger, J.M., Kreinin, M.E. (1979) A measure of 'export similarity' and its possible uses. The Economic Journal, 78: 905-912.

Florida, R. (2005) Cities and the Creative Class. New York: Routledge.

Fotheringham, A.S., O'Kelly, M.E. (1989) Spatial Interaction Models: Formulations and Applications. Dordrecht: Kluwer. 
Glaeser, E.L., Kohlhase, J.E. (2004). Cities, regions and the decline of transport costs. Papers in Regional Science, 83: 197-228.

Globerman, S., Chen, V.Z. (2010) Best Policy Practices for Promoting Inward and Outward Foreign Direct Investment. Ottawa, The Conference Board of Canada.

Gordon, I.R. (1999) Internationalisation and urban competition, Urban Studies, 36: 10011016.

Hannan, M.T., Freeman, J.H. (1977) The population ecology of organizations. American Journal of Sociology, 82: 929-964.

Head, K., Mayer, T., Ries, J. (2009). How remote is the offshoring threat? European Economic Review, 53: 429-444.

Hewings, G.J.D., Sonis, M., Cuello, F.A., Mansouri, F. (1996) The role of regional interaction in regional growth: competition and complementarity in the US regional system. Australasian Journal of Regional Studies, 2: 133-149.

Hymer, S. (1970) The efficiency contradictions of multinational corporations. American Economic Review, 60: 441-448.

Johanson, J., Vahlne, J.E. (1977) The internationalization process of the firm - a model of knowledge development and increasing foreign market commitments. Journal of International Business Studies, 8: 23-32.

Jenkins, R. (2008) Measuring the competitive threat from China for other southern exporters. The World Economy, 31: 1351-1366.

Kellman, M., Schroder, T. (1983) The export similarity index: some structural tests. The Economic Journal, 93: 193-198.

Kitson, M., Martin, R., Tyler, P. (2004) Regional competiveness: an elusive yet key concept. Regional Studies, 38: 991-999.

Kresl, P.K., Singh, B. (1999) Competitiveness and the urban economy: twenty-four large US metropolitan areas. Urban Studies, 36: 1017-1027.

Lall, S., Pietrobelli, C. (2005) Failing to Compete. Technology Development and Technology Systems in Africa. Cheltenham: Edward Elgar.

LeRoy, G. (2005) The Great American Job Scam: Corporate Tax Dodging and the Myth of Job Creation, San Francisco, CA: Berett-Koehler Publishers.

Lever, W.F. (1999) Competitive cities in Europe. Urban Studies, 36: 935-948.

Luque-Martínez, T., Muñoz-Leiva, F. (2005) City benchmarking: a methodological proposal referring specifically to Granada. Cities, 22: 411-423. 
Malecki, E.J. (2002) Hard and soft networks for urban competitiveness. Urban Studies, 39: 929-945.

Malecki, E.J. (2004) Jockeying for position: what it means and why it matters to regional development policy when places compete. Regional Studies, 38: 1101-1120.

Markusen, A.R. (1996), Sticky places in slippery space: a typology of industrial districts. Economic Geography, 72: 293-313.

Markusen, A.R., Nesse, K. (2007) Institutional and political determinants of incentive competition. In A.R. Markusen (ed.), Reining in the Competition for Capital. Kalamazoo, MI: W.E. Upjohn Institute for Employment Research, pp. 1-42.

Márquez, M.A., Hewings, G.J.D. (2003) Geographical competition between regional economies: the case of Spain. Annals of Regional Science, 37: 559-580.

Mataloni Jr., R.J. (2011) The structure of location choice for new U.S. manufacturing investments in Asia-Pacific. Journal of World Business, 46: 154-165.

McCann, E.J. (2004) 'Best places': interurban competition, quality of life and popular media discourse. Urban Studies, 41: 1909-1929.

McCann P, 2008, Globalization and economic geography: the world is curved, not flat. Cambridge Journal of Regions, Economy and Society, 1: 351-370.

McCann, P. (2011) International business and economic geography: knowledge, time and transactions costs. Journal of Economic Geography, 11: 309-317.

McPherson, M. (1983) An ecology of affiliations. American Sociological Review, 48: 519532.

Mencinger, J. (2008) Does foreign investment always enhance economic growth? Kyklos, 56: 491-508

Narula, R., Bellak, C. (2009) EU enlargement and consequences for FDI assisted industrial development. Transnational Corporations, 18: 69-90.

Neary, J.P. (2002) Foreign direct investment and the single market. Manchester School, 70: 291-314.

Openshaw S., Taylor, P.J. (1979), “A million or so correlation coefficients: three experiments on the modifiable areal unit problem. In: N. Wrigley, Statistical Applications in the Spatial Sciences, London: Pion, pp. 127-144.

Paddison, R. (1993) City marketing, image reconstruction and urban regeneration. Urban Studies, 30: 339-349.

Phelps, N.A., Fuller, C. (2000) Multinationals, intracorporate competition and regional development. Economic Geography, 76: 224-243. 
Phelps, N.A., Lovering, J., Morgan, K. (1998) Tying the firm to the region or tying the region to the firm? Early observations on the case of LG in South Wales. European Urban and Regional Studies, 5: 119-137.

Phelps, N.A, Raines, P. (2003) Conclusions: who's competing with whom? In: N. Phelps, P. Raines (eds) The New Competition for Inward Investment. Cheltenham: Edward Elgar, pp. 213-221.

Phelps, N.A., Tewdwr-Jones, M. (2001) Globalisation, regions and the state: exploring the limitations of economic modernisation through inward investment. Urban Studies, 38: $1253-1272$.

Phelps, N.A., Wu, F. (2009) Capital's search for order: foreign direct investment and modes of social order in East and Southeast Asia. Political Geography, 28: 44-54.

Podolny, J.M, Stuart, T.E., Hannan, M.T. (1996) Networks knowledge and niches competition in the worldwide semiconductor industry 1984-1991. American Journal of Sociology, 102: 659-689.

Poot, J. (2000), Reflections on local and economy-wide effects of territorial competition. In: P. Friedrich, P.W.J. Batey, Regional Competition. Heidelberg: Springer, pp. 205-230.

Porter (2000), Location, competition, and economic development: local clusters in a global economy. Economic Development Quarterly, 14: 15-34.

Raines, P. (2003) Flows and territories: the new geography of competition for mobile investment in Europe. In N. Phelps, P. Raines (eds) The New Competition for Inward Investment, Cheltenham, UK: Edward Elgar, pp. 119-136.

Rogerson, R.J. (1999), Quality of life and city competitiveness. Urban Studies, 36: 969-985.

Rugman, A.M., Verbeke, A. (2005) Towards a theory of regional multinationals: a transaction cost economics approach. Management International Review, Special Issue 2005/1, 5-17.

Scott, A., Storper, M. (2007), Regions, globalization and development. Regional Studies, 41: 191-205

Sonis, M., Hewings, G.J.D. (2000), Regional competition and complementarity; comparative advantages/disadvantages and increasing/dimininshing returns in discrete relative spatial dynamics. In P. Friedrich, P.W.J. Batey, Regional Competition. Heidelberg: Springer, pp. $139-158$

Storper, M. (1997) The Regional World: Territorial Development in a Global Economy. New York: Guilford Press.

Taylor, P.J. (2004) World City Network: A Global Urban Analysis. London: Routledge. 
Taylor, P.J. (2010) Competition and cooperation between cities in globalization. GaWC Research Bulletin 351.

Tewdwr-Jones, M., Phelps, N.A. (2000) Levelling the uneven playing field: inward investment, inter-regional rivalry and the planning system. Regional Studies, 34: 429-440.

Thissen, M., Van Oort, F.G., Burger, M.J., Diodato, D. and Ruijs, A. (2012) Revealed competition and comparative advantage of European regions. Working paper, Netherlands Environmental Assessment Agency, The Hague.

Turok, I. (2004) Cities, regions and competitiveness. Regional Studies, 38: 1069-1083.

Turok, I. (2009) The distinctive city: pitfalls in the pursuit of differential advantage. Urban Studies, 41: 13-30.

UNCTAD (2001) World Investment Report 2001: Promoting Linkages. New York, NY: United Nations.

Van der Berg, L., Braun, E. (1999) Urban competitiveness, marketing and the need for organising capacity. Urban Studies, 36: 987-999.

Van Oort, F.G. (2004) Urban Growth and Innovation: Spatially Bounded Externalities in the Netherlands. Aldershot: Ashgate.

Van Oort, F.G., Burger, M.J, Raspe, O. (2010) On the economic foundations of the urban network paradigm. Spatial integration, functional integration and urban complementarities in the Dutch Randstad. Urban Studies, 47, 725-748.

Wall, R.S., Burger, M.J., Van der Knaap, G.A. (2011) The geography of global corporate networks: the poor, the rich and the happy few countries. Environment and Planning A, 43: 904-927.

Young, S., Hood, N., Wilson, A. (1994) Targeting policy as a competitive strategy for European inward investment agencies. European Urban and Regional Studies, 1: 143-159. 
Appendix A: Taxonomy of Investments by Sector and Function

\begin{tabular}{|c|c|}
\hline Category & Sectors \\
\hline $\begin{array}{l}\text { Processing Industries and Natural Resource } \\
\text { Extraction }\end{array}$ & $\begin{array}{l}\text { Alternative/Renewable Energy } \\
\text { Chemicals } \\
\text { Coal, Oil \& Natural Gas } \\
\text { Minerals }\end{array}$ \\
\hline Low-Tech Manufacturing & $\begin{array}{l}\text { Beverages } \\
\text { Ceramics \& Glass } \\
\text { Consumer Products } \\
\text { Food \& Tobacco } \\
\text { Metals } \\
\text { Paper, Printing \& Packaging } \\
\text { Plastics } \\
\text { Rubber } \\
\text { Textiles } \\
\text { Wood Products }\end{array}$ \\
\hline Medium-Tech Manufacturing & $\begin{array}{l}\text { Automotive Components } \\
\text { Automotive OEM } \\
\text { Building \& Construction Materials } \\
\text { Engines \& Turbines } \\
\text { Industrial Machinery } \\
\text { Non-Automotive Transport OEM }\end{array}$ \\
\hline High-Tech Manufacturing & $\begin{array}{l}\text { Aerospace } \\
\text { Biotechnology } \\
\text { Business Machines \& Equipment } \\
\text { Consumer Electronics } \\
\text { Electronics Components } \\
\text { Medical Devices } \\
\text { Pharmaceuticals } \\
\text { Semiconductors }\end{array}$ \\
\hline Transport Services & $\begin{array}{l}\text { Transportation } \\
\text { Warehousing \& Storage }\end{array}$ \\
\hline $\begin{array}{l}\text { Software and Information and Communication } \\
\text { Technologies }\end{array}$ & $\begin{array}{l}\text { Communications } \\
\text { Software \& IT Services } \\
\text { Space \& Defense }\end{array}$ \\
\hline Financial Services & Financial Services \\
\hline Commercial Services & $\begin{array}{l}\text { Business Services } \\
\text { Real Estate }\end{array}$ \\
\hline Consumer Services & $\begin{array}{l}\text { Healthcare } \\
\text { Hotels \& Tourism } \\
\text { Leisure \& Entertainment }\end{array}$ \\
\hline
\end{tabular}




\begin{tabular}{|l|l|}
\hline Category & Functions \\
\hline Headquarters & Headquarters \\
\hline Business Services & Business Services \\
\hline Research and Development & $\begin{array}{l}\text { Design, Development, and Testing } \\
\text { Research and Development }\end{array}$ \\
\hline Sales and Marketing & $\begin{array}{l}\text { Retail } \\
\text { Sales, Marketing, and Support }\end{array}$ \\
\hline Production & Electricity \\
& Extraction \\
& Construction \\
& Manufacturing \\
& Recycling \\
\hline Support and Servicing & Customer Contact Centres \\
& Education and Training \\
& ICT and Internet Infrastructure \\
& Maintenance \\
& Shared Service Centres \\
& Technical Support Centres \\
\hline Logistics & Logistics \\
\hline
\end{tabular}


Figure 1: Distribution of Inward Investments across Sectors

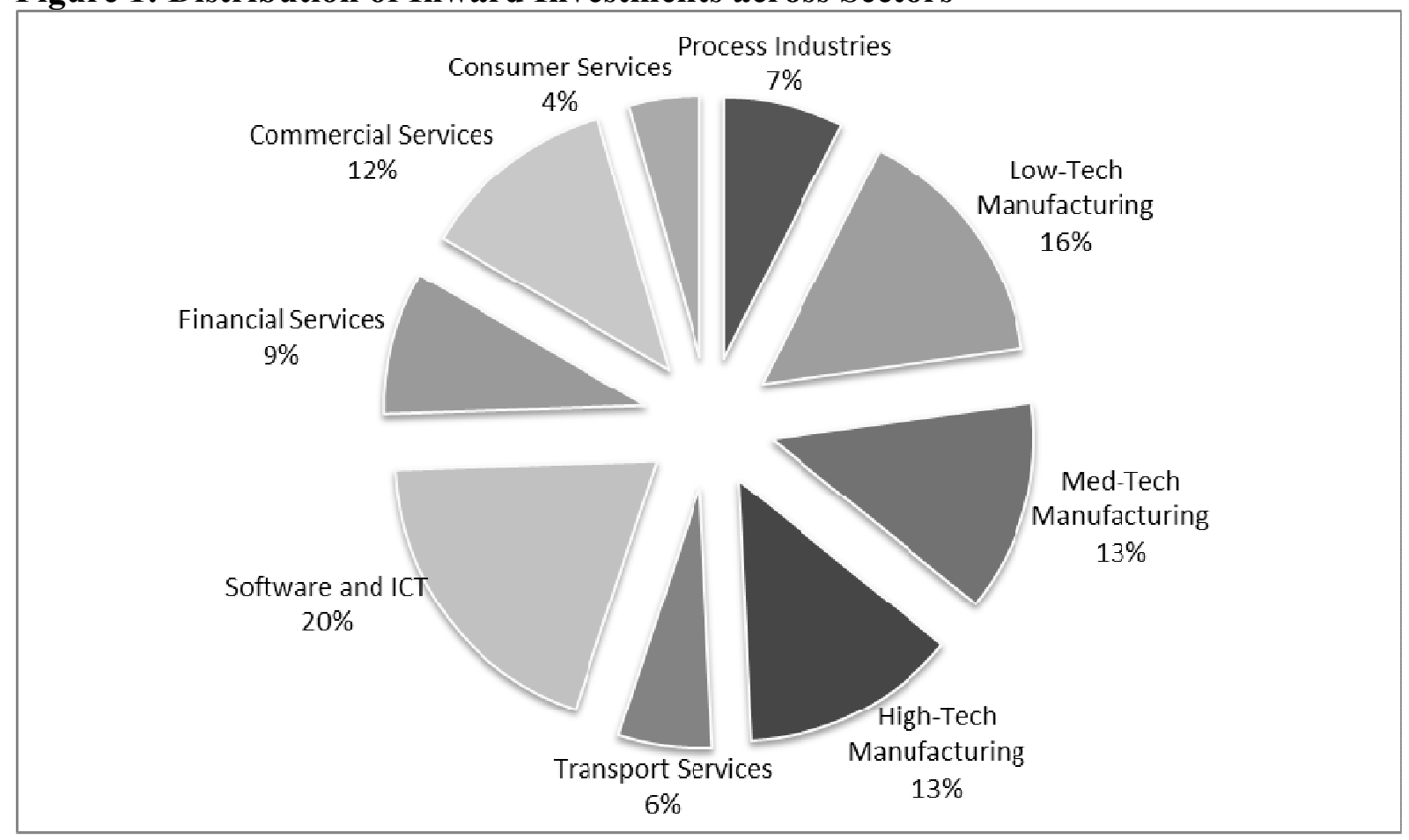


Figure 2: Distribution of Inward Investments across Functions

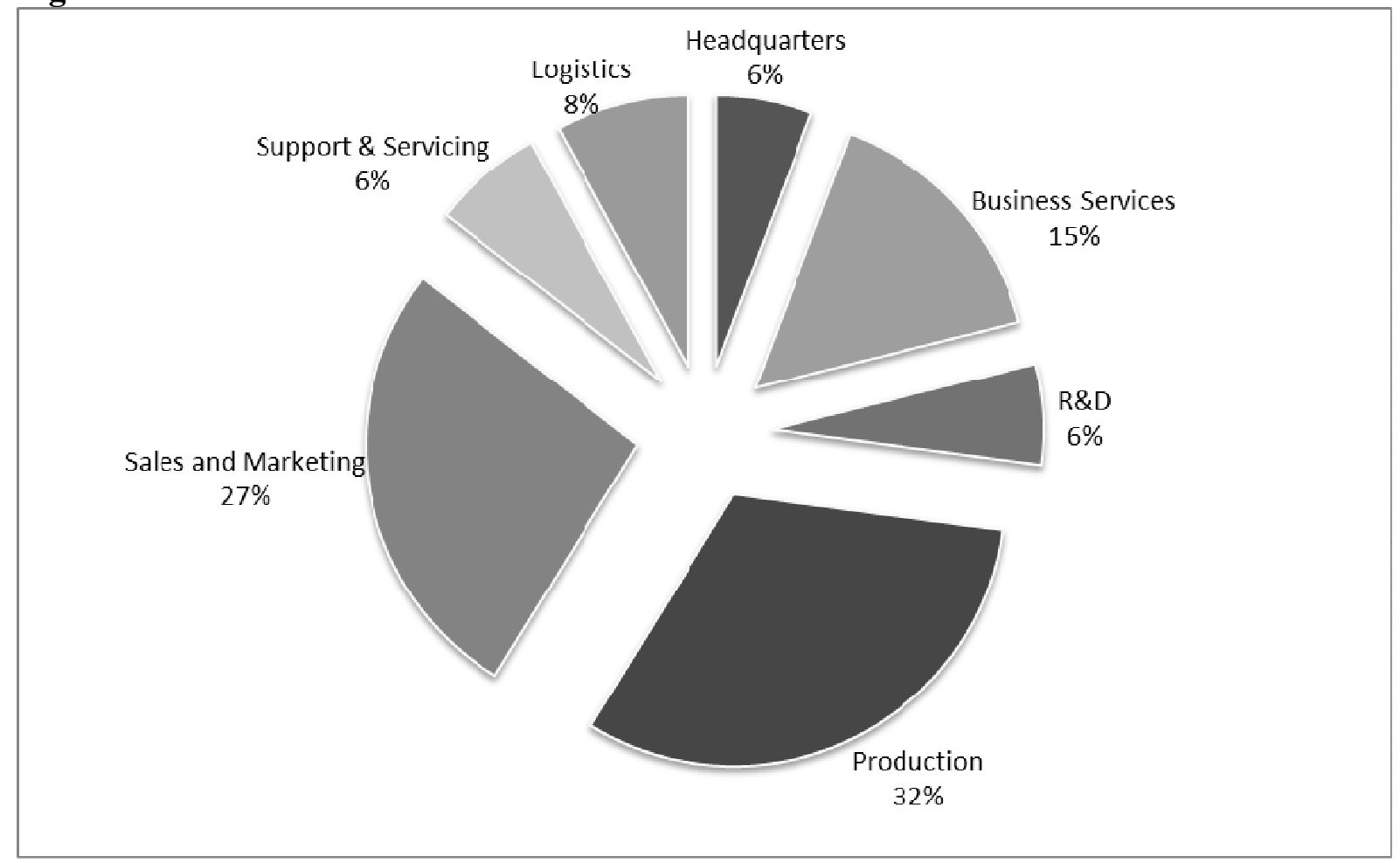


Figure 3: Distribution of Inward Investments across World Regions

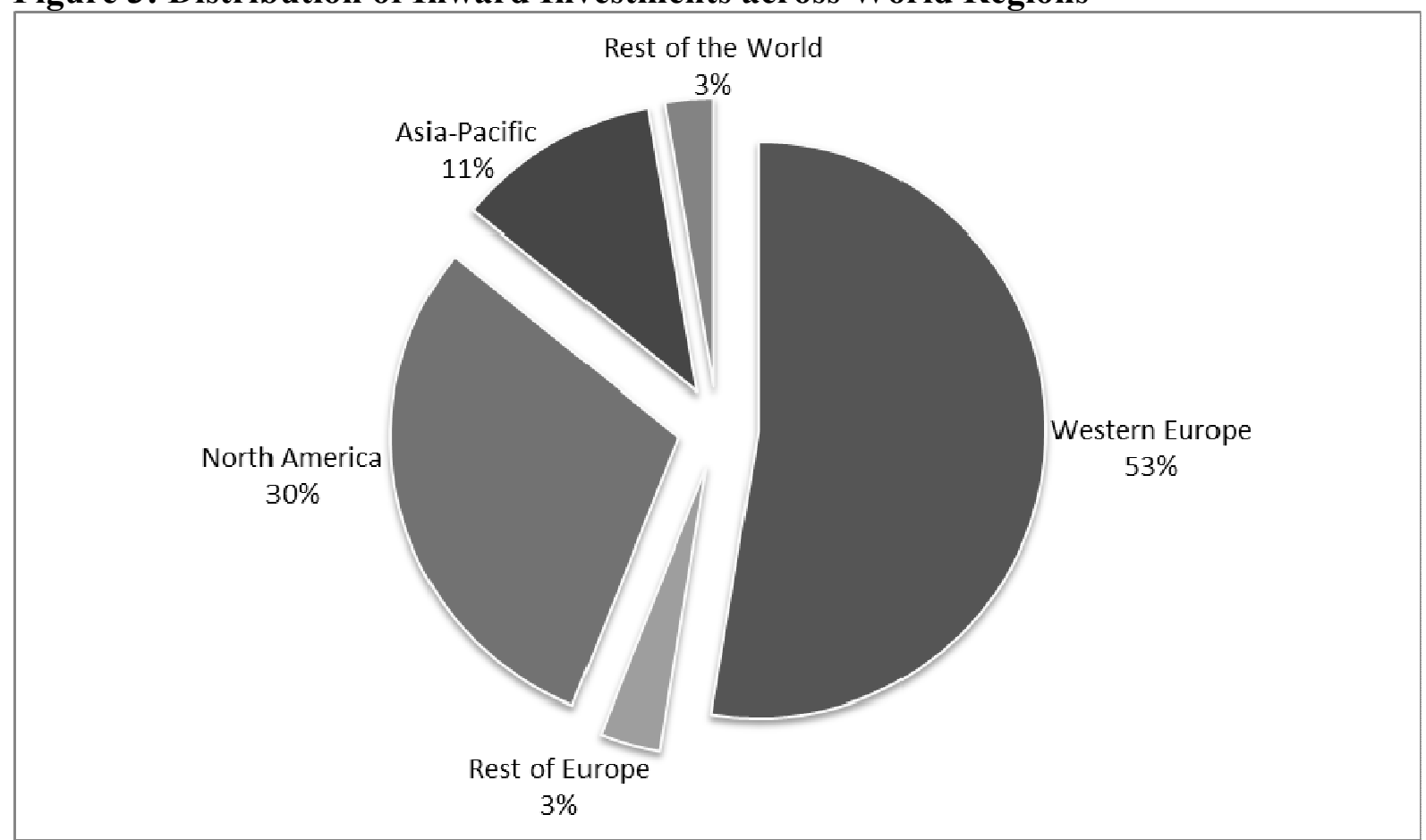

Note: rest of the world includes Africa, Middle East, an Latin America 
Table 1: Investment Portfolios of the Top 20 NUTS-2 Regions

\begin{tabular}{|c|c|c|c|c|c|}
\hline Rank & Region & Name (Main City) & $\begin{array}{l}\text { Number of } \\
\text { Investments } \\
\text { (\% of total) }\end{array}$ & Sector Specialization(s) (LQ>1.2) & $\begin{array}{l}\text { Function Specialization(s) } \\
\text { (LQ>1.2) }\end{array}$ \\
\hline 1 & UKI & Greater London & $1814(6.7 \%)$ & $\begin{array}{l}\text { Financial Services, ICT, Commercial } \\
\text { Services, Consumer Services }\end{array}$ & $\begin{array}{l}\text { Business Services, Sales and } \\
\text { Marketing, Headquarters }\end{array}$ \\
\hline 2 & FR10 & Ile-de-France (Paris) & $1176(4.4 \%)$ & ICT, Commercial Services & $\begin{array}{l}\text { Sales and Marketing, Business } \\
\text { Services }\end{array}$ \\
\hline 3 & IE02 & $\begin{array}{l}\text { Southern and Eastern } \\
\text { Ireland (Dublin) }\end{array}$ & $781(2.9 \%)$ & $\begin{array}{l}\text { Financial Services, ICT, High-tech } \\
\text { Manufacturing, Consumer Services }\end{array}$ & $\begin{array}{l}\text { Headquarters, R\&D, Support } \\
\text { and Servicing, Business } \\
\text { Services }\end{array}$ \\
\hline 4 & ES30 & $\begin{array}{l}\text { Communidad de } \\
\text { Madrid }\end{array}$ & $613(2.3 \%)$ & & \\
\hline 5 & ES51 & Cataluña (Barcelona) & $563(2.2 \%)$ & Low-tech Manufacturing, Transport & R\&D, Headquarters, Logistics \\
\hline 6 & DEA1 & Düsseldorf & $526(2.1 \%)$ & $\begin{array}{l}\text { Low-tech Manufacturing, Commercial } \\
\text { services }\end{array}$ & $\begin{array}{l}\text { Headquarters, Sales and } \\
\text { Marketing, Business Services }\end{array}$ \\
\hline 7 & HU10 & $\begin{array}{l}\text { Közép-Magyar. } \\
\text { (Budapest) }\end{array}$ & $545(2.0 \%)$ & $\begin{array}{l}\text { Consumer Services, Commercial } \\
\text { Services }\end{array}$ & Support and Servicing, R\&D \\
\hline 8 & PL12 & Mazovia (Warsaw) & $536(2.0 \%)$ & $\begin{array}{l}\text { Commercial Services, Transport, } \\
\text { Financial Services }\end{array}$ & - \\
\hline 9 & DE21 & Oberbayern (Munich) & $497(1.6 \%)$ & $\begin{array}{l}\text { ICT, High-tech Manufacturing, } \\
\text { Commercial Services }\end{array}$ & $\begin{array}{l}\text { Sales and Marketing, Business } \\
\text { Services, R\&D }\end{array}$ \\
\hline 10 & DE71 & Darmstadt (Frankfurt) & $427(1.4 \%)$ & $\begin{array}{l}\text { Financial Services, ICT, Commercial } \\
\text { Services }\end{array}$ & $\begin{array}{l}\text { Business Services, Sales and } \\
\text { Marketing, Support and } \\
\text { Servicing }\end{array}$ \\
\hline 11 & ITC4 & Lombardia (Milan) & $407(1.5 \%)$ & $\begin{array}{l}\text { Financial Services, High-tech } \\
\text { Manufacturing, ICT }\end{array}$ & $\begin{array}{l}\text { Sales and Marketing, Business } \\
\text { Services }\end{array}$ \\
\hline 12 & NL32 & $\begin{array}{l}\text { Noord-Holland } \\
\text { (Amsterdam) }\end{array}$ & $382(1.4 \%)$ & $\begin{array}{l}\text { ICT, Financial Services, Commercial } \\
\text { Services }\end{array}$ & $\begin{array}{l}\text { Headquarters, Support and } \\
\text { Servicing, Business Services }\end{array}$ \\
\hline 13 & FR71 & Rhône-Alpes (Lyon) & $372(1.4 \%)$ & $\begin{array}{l}\text { High-tech Manufacturing, Medium-Tech } \\
\text { Manufacturing, Process Industries, } \\
\text { Transport }\end{array}$ & $\begin{array}{l}\text { Sales and Marketing, } \\
\text { Headquarters }\end{array}$ \\
\hline 14 & $\mathrm{CZ} 01$ & Praha (Praha) & $349(1.3 \%)$ & $\begin{array}{l}\text { Consumer Services, Commercial } \\
\text { Services, Financial Services, Transport }\end{array}$ & $\begin{array}{l}\text { Business Services, R\&D, Sales } \\
\text { and Marketing }\end{array}$ \\
\hline 15 & DK01 & $\begin{array}{l}\text { Hovedstaden } \\
\text { (Copenhagen) }\end{array}$ & $347(1.3 \%)$ & $\begin{array}{l}\text { ICT, Commercial Services, High-tech } \\
\text { Manufacturing }\end{array}$ & $\begin{array}{l}\text { Headquarters, Business } \\
\text { Services, Sales and Marketing, } \\
\text { R\&D }\end{array}$ \\
\hline 16 & SE11 & Stockholm & $318(1.2 \%)$ & $\begin{array}{l}\text { Financial Services, ICT, Commercial } \\
\text { Services }\end{array}$ & $\begin{array}{l}\text { Business Services, Sales and } \\
\text { Marketing }\end{array}$ \\
\hline 17 & UKJ1 & $\begin{array}{l}\text { East Anglia } \\
\text { (Cambridge) }\end{array}$ & $303(1.1 \%)$ & ICT, High-tech Manufacturing & $\begin{array}{l}\text { Headquarters, Sales and } \\
\text { Marketing, R\&D, Support and } \\
\text { Servicing, }\end{array}$ \\
\hline 18 & AT13 & Wien & $299(1.1 \%)$ & $\begin{array}{l}\text { Consumer Services, Financial Services, } \\
\text { Commercial Services }\end{array}$ & $\begin{array}{l}\text { Business Services, } \\
\text { Headquarters, Sales and } \\
\text { Marketing }\end{array}$ \\
\hline 19 & PL51 & $\begin{array}{l}\text { Lower Silesia } \\
\text { (Wroclaw) }\end{array}$ & $292(1.1 \%)$ & $\begin{array}{l}\text { Medium-tech Manufacturing, High-tech } \\
\text { Manufacturing, Low-tech } \\
\text { Manufacturing }\end{array}$ & Production plants \\
\hline 20 & BE10 & Brussels & $281(1.0 \%)$ & Commercial Services, ICT & $\begin{array}{l}\text { Business Services, } \\
\text { Headquarters, Sales and } \\
\text { Marketing }\end{array}$ \\
\hline
\end{tabular}


Table 2: Revealed Competition across Sector, Function, and World Region of Origin

\begin{tabular}{|c|c|c|c|}
\hline Sector & Overlap & $\begin{array}{c}\text { Share of regions that } \\
\text { receive at least one } \\
\text { investment }\end{array}$ & $\begin{array}{c}\text { Share of inward } \\
\text { investments of top } 10 \\
\text { regions }\end{array}$ \\
\hline Low-tech Manufacturing & 0.355 & 0.932 & 0.184 \\
\hline Process Industries & 0.343 & 0.883 & 0.194 \\
\hline Transport Services & 0.293 & 0.826 & 0.233 \\
\hline Medium-tech Manufacturing & 0.266 & 0.902 & 0.205 \\
\hline High-tech Manufacturing & 0.241 & 0.890 & 0.256 \\
\hline Software and ICT & 0.208 & 0.845 & 0.448 \\
\hline Commercial Services & 0.206 & 0.837 & 0.401 \\
\hline Consumer Services & 0.201 & 0.652 & 0.344 \\
\hline Financial Services & 0.190 & 0.667 & 0.456 \\
\hline Function & Overlap & $\begin{array}{c}\text { Share of regions that } \\
\text { receive at least one } \\
\text { investment }\end{array}$ & $\begin{array}{c}\text { Share of inward } \\
\text { investments of top } 10 \\
\text { regions } \\
\end{array}$ \\
\hline Production Plants & 0.351 & 0.977 & 0.172 \\
\hline Logistics & 0.274 & 0.867 & 0.212 \\
\hline Sales and Marketing & 0.216 & 0.883 & 0.393 \\
\hline Business Services & 0.203 & 0.818 & 0.423 \\
\hline R\&D & 0.171 & 0.761 & 0.290 \\
\hline Support and Servicing & 0.171 & 0.777 & 0.312 \\
\hline Headquarters & 0.108 & 0.595 & 0.444 \\
\hline World Region of Origin & Overlap & $\begin{array}{c}\text { Share of regions that } \\
\text { receive at least one } \\
\text { investment }\end{array}$ & $\begin{array}{c}\text { Share of inward } \\
\text { investments of top } 10 \\
\text { regions }\end{array}$ \\
\hline Western Europe & 0.332 & 0.992 & 0.237 \\
\hline North America & 0.225 & 0.936 & 0.367 \\
\hline Asia-Pacific & 0.170 & 0.837 & 0.332 \\
\hline Rest of Europe & 0.082 & 0.564 & 0.367 \\
\hline Latin America & 0.031 & 0.258 & 0.532 \\
\hline Africa & 0.020 & 0.231 & 0.448 \\
\hline
\end{tabular}


Table 3: Most Competitive Market Segments in European Market for Investments

\begin{tabular}{|ccclll|}
\hline Rank & $\begin{array}{c}\text { Number of } \\
\text { Investments }\end{array}$ & Overlap & \multicolumn{1}{c}{ Sector } & \multicolumn{1}{c}{ Function } & $\begin{array}{c}\text { World Region of } \\
\text { Origin }\end{array}$ \\
\hline 1 & 921 & 0.454 & Processing Industries & Production & Western Europe \\
3 & 1707 & 0.437 & Low-tech Manufacturing & Production & Western Europe \\
4 & 766 & 0.406 & Transport Services & Logistics & Western Europe \\
5 & 486 & 0.397 & Low-tech Manufacturing & Production & North America \\
6 & 573 & 0.354 & High-tech Manufacturing & Production & Western Europe \\
7 & 1206 & 0.346 & Medium-tech Manufacturing & Production & Western Europe \\
8 & 316 & 0.338 & Low-tech Manufacturing & Logistics & Western Europe \\
9 & 1181 & 0.300 & Software and ICT & Sales and Marketing & Western Europe \\
10 & 407 & 0.296 & Consumer Services & Production ${ }^{\text {a }}$ & Western Europe \\
\hline a This mainly include the construction of hotels and entertainment facilities & & Business Services & Western Europe \\
\hline
\end{tabular}


Table 4: Least Competitive Large Market Segments in European Market for Investments

\begin{tabular}{|c|c|c|c|c|}
\hline $\begin{array}{c}\text { Number of } \\
\text { Investments }\end{array}$ & Overlap & Sector & Function & World Region of Origin \\
\hline 341 & 0.079 & Financial Services & Business Services & Asia-Pacific \\
\hline 100 & 0.098 & Consumer Services & Production $^{\mathrm{a}}$ & Middle East \\
\hline 159 & 0.100 & Financial Services & Business Services & Rest of Europe \\
\hline 355 & 0.114 & Software and ICT & Headquarters & North America \\
\hline 106 & 0.119 & Software and ICT & Business Services & North America \\
\hline 118 & 0.132 & Financial Services & Business Services & North America \\
\hline 421 & 0.135 & Financial Services & Sales and Marketing & North America \\
\hline 188 & 0.136 & Financial Services & Sales and Marketing & Western Europe \\
\hline 150 & 0.137 & Low-tech Manufacturing & Sales and Marketing & Asia-Pacific \\
\hline 134 & 0.142 & Consumer Services & Sales and Marketing & Western Europe \\
\hline
\end{tabular}


Table 5: Main Competitive Relationships of Greater London and Lower Silesia

\begin{tabular}{|c|c|c|c|c|c|c|c|}
\hline \multicolumn{4}{|c|}{ Competitive threat posed on Greater London: } & \multicolumn{4}{|c|}{ Competitive threat posed on Lower Silesia: } \\
\hline Code & Region name & Main city & Overlap & Code & Region name & Main city & Overlap \\
\hline FR10 & Ile-de-France & Paris & 0.588 & SK02 & Západné Slovensko & Nitra & 0.651 \\
\hline IE02 & Southern and Eastern Ireland & Dublin & 0.367 & ES51 & Cataluña & Barcelona & 0.641 \\
\hline ES30 & Communidad de Madrid & Madrid & 0.366 & PL22 & Silesia (Slaskie) & Katowice & 0.605 \\
\hline DE21 & Oberbayern & Munich & 0.345 & HU21 & Közép-Dunántúl & Székesfehérvár & 0.584 \\
\hline DE71 & Darmstadt & Frankfurt & 0.299 & HU10 & Közép-Magyarország & Budapest & 0.577 \\
\hline NL32 & Noord-Holland & Amsterdam & 0.289 & PL12 & Mazowiecki & Warsaw & 0.556 \\
\hline ITC4 & Lombardia & Milan & 0.279 & HU22 & Nyugat-Dunántúl & Gyor & 0.546 \\
\hline PL12 & Mazowiecki & Warsaw & 0.258 & FR71 & Rhône-Alpes & Lyon & 0.535 \\
\hline DEA1 & Düsseldorf & Düsseldorf & 0.252 & EE00 & Estonia & Tallinn & 0.515 \\
\hline DK01 & Hovedstaden & Copenhagen & 0.258 & PL41 & Wielkopolskie & Poznan & 0.493 \\
\hline \multicolumn{4}{|c|}{ Greater London posing competitive threat to: } & \multicolumn{4}{|c|}{ Lower Silesia posing competitive threat to: } \\
\hline Code & Region name & Main city & Overlap & Code & Region name & Main city & Overlap \\
\hline FR10 & Ile-de-France & Paris & 0.687 & SK02 & Západné Slovensko & Nitra & 0.812 \\
\hline NL13 & Drenthe & Assen & 0.679 & PL22 & Silesia (Slaskie) & Katowice & 0.688 \\
\hline ES13 & Cantabria & Santander & 0.608 & HU21 & Közép-Dunántúl & Székesfehérvár & 0.687 \\
\hline DEB1 & Koblenz & Koblenz & 0.580 & HU22 & Nyugat-Dunántúl & Gyor & 0.674 \\
\hline $\mathrm{BE} 25$ & West-Vlaanderen & Brugge & 0.575 & FI1A & Pohjois-Suomi & Oulu & 0.610 \\
\hline ES30 & Communidad de Madrid & Madrid & 0.573 & PL11 & Lódzkie & Lódz & 0.593 \\
\hline NL34 & Zeeland & Middelburg & 0.569 & $\mathrm{CZ04}$ & Severozápad & Ústí nad Labem & 0.592 \\
\hline PL33 & Swietokrzyskie & Kielce & 0.566 & FR41 & Lorraine & Metz & 0.592 \\
\hline PL52 & Opolskie & Opole & 0.558 & ITC3 & Liguria & Genoa & 0.589 \\
\hline AT34 & Vorarlberg & Bregenz & 0.548 & HU32 & Észak-Alföld & Debrecen & 0.583 \\
\hline
\end{tabular}


Table 6: Variables Included in the Regression Models

\begin{tabular}{|c|c|c|}
\hline Variable & Description & Source \\
\hline Natural resource intensity difference & Absolute difference of share of employment in mining and energy of region $i$ and $j$ & $\mathrm{CE}$ \\
\hline Market size difference & Absolute difference of log of value added of regions $i$ and $j$ & $\mathrm{CE}$ \\
\hline GDP per capita difference & Absolute difference of $\log$ of (regional GDP/population) of regions $i$ and $j$ & $\mathrm{CE}$ \\
\hline Accessibility by air difference & Absolute difference of $\log$ of accessibility by air index of regions $i$ and $j$ & ESPON \\
\hline Accessibility by road and rail difference & Absolute difference of log of accessibility by rail and road index of regions $i$ and $j$ & ESPON \\
\hline Wage per hour difference & Absolute difference of log of (wages/total hours worked) of regions $i$ and $j$ & $\mathrm{CE}$ \\
\hline Population density difference & Absolute difference of log of (regional population / total area in $\mathrm{km}^{2}$ ) of regions $i$ and $j$ & $\mathrm{CE}$ \\
\hline R\&D intensity rate difference & Absolute difference of R\&D expenditures as $\%$ of GDP of regions $i$ and $j$ & Eurostat \\
\hline University degree rate difference & Absolute difference share of population ( $>15)$ with university degree rate (ISCED 5-6) of regions $i$ and $j$ & Eurostat \\
\hline Social charges rate difference & Absolute difference of social charges rate of region $i$ and $j$ (measured at country level) & EY HC \\
\hline Corporate tax rate difference & Absolute difference of statutory corporate tax rate of regions $i$ and $j$ (measured at country level) & EY Tax \\
\hline Physical distance & Log of the geodesic distance between region $i$ and $j$ & - \\
\hline Country dissimilarity & Takes value 1 when located in a different country & - \\
\hline
\end{tabular}


Table 7: OLS on Revealed Competition between Regions

\begin{tabular}{|c|c|c|}
\hline & $\begin{array}{c}\text { Model } 1 \\
\operatorname{Ln}\left(C_{i j}\right)\end{array}$ & $\begin{array}{l}\text { Model } 2 \\
\operatorname{Ln}\left(C_{i j}\right)\end{array}$ \\
\hline Regional level & & \\
\hline Market size difference & $-0.00(.007)$ & $-0.00(.007)$ \\
\hline GDP per capita difference & $-0.08(.018)^{* *}$ & $-0.08(.018)^{* *}$ \\
\hline Accessibility by air difference & $-0.26(.020)^{* *}$ & $-0.26(.020)^{* *}$ \\
\hline Accessibility by rail and road difference & $-0.05(.007)^{* *}$ & $-0.05(.007)^{* *}$ \\
\hline Population density difference & $-0.03(.005)^{* *}$ & $-0.03(.005)^{* *}$ \\
\hline Wage per hour difference & $-0.09(.021)^{* *}$ & $-0.09(.021)^{* *}$ \\
\hline R\&D Expenditures difference & $-0.42(.385)$ & $-0.38(.386)$ \\
\hline University degree rate difference & $-0.25(.052)^{* *}$ & $-0.24(.053) * *$ \\
\hline Natural resource intensity difference & $0.60(.710)$ & $0.58(.701)$ \\
\hline Physical distance & $-0.07(.007)^{* *}$ & $-0.05(.007)^{* *}$ \\
\hline \multicolumn{3}{|l|}{ Country level } \\
\hline Social charges rate difference & $0.00(.086)$ & \\
\hline Corporate tax rate difference & $-0.05(.077)$ & \\
\hline Situated in different country & & $-0.07(.013)^{* *}$ \\
\hline Observations & 59780 & 59780 \\
\hline 'Importer' fixed effects & YES & YES \\
\hline ‘Exporter' fixed effects & YES & YES \\
\hline R-squared & 0.67 & 0.67 \\
\hline Root MSE & 0.72 & 0.72 \\
\hline
\end{tabular}


Table 8: Regions facing largest (smallest) competitive threat from other regions and regions posing the largest competitive threat to other regions

\begin{tabular}{|c|c|c|c|c|c|c|c|}
\hline \multicolumn{4}{|c|}{ Facing smallest competitive threat from other regions } & \multicolumn{4}{|c|}{ Posing largest competitive threat to other regions } \\
\hline Code & Region name & Main city & Average Overlap & Code & Region name & Main city & Average Overlap \\
\hline UKI1 & Greater London & London & 0.050 & ITC4 & Lombardia & Milan & 0.384 \\
\hline FR10 & Ile-de-France & Paris & 0.081 & DEA2 & Köln & Köln & 0.379 \\
\hline IE02 & Southern and Eastern Ireland & Dublin & 0.109 & UKM3 & South Western Scotland & Glasgow & 0.371 \\
\hline DEA1 & Düsseldorf & Düsseldorf & 0.133 & DE71 & Darmstadt & Frankfurt & 0.365 \\
\hline DE21 & Oberbayern & Munich & 0.134 & $\mathrm{CZ} 01$ & Praha & Prague & 0.355 \\
\hline NL32 & Noord-Holland & Amsterdam & 0.138 & ES61 & Andalucia & Sevilla & 0.353 \\
\hline DE71 & Darmstadt & Frankfurt & 0.140 & FR71 & Rhône-Alpes & Lyon & 0.352 \\
\hline ES30 & Communidad de Madrid & Madrid & 0.142 & UKM2 & Eastern Scotland & Edinburgh & 0.349 \\
\hline UKJ1 & Berkshire, Bucks, and Oxfordshire & Oxford & 0.145 & DE21 & Oberbayern & Munich & 0.345 \\
\hline ES51 & Cataluña & Barcelona & 0.148 & ES30 & Communidad de Madrid & Madrid & 0.343 \\
\hline \multicolumn{4}{|c|}{ Facing largest competitive threat from other regions } & \multicolumn{4}{|c|}{ Posing smallest competitive threat to other regions } \\
\hline Code & Region name & Main city & Average Overlap & Code & Region name & Main city & Average Overlap \\
\hline GR41 & Voreio Aigaio & Mytilene & 0.519 & GR13 & Dytiki Makedonia & Kozani & 0.005 \\
\hline DEB2 & Trier & Trier & 0.477 & NO06 & Trøndelag & Trondheim & 0.009 \\
\hline PT20 & Azores & Ponta Delgada & 0.470 & GR11 & Anatoliki Makedonia & Komotini & 0.009 \\
\hline ITE2 & Umbria & Perugia & 0.450 & FR83 & Corse & Ajaccio & 0.020 \\
\hline NL34 & Zeeland & Middelburg & 0.425 & GR21 & Ipeiros & Ioannina & 0.024 \\
\hline GR24 & Sterea Ellada & Lamia & 0.419 & GR25 & Peloponnese & Tripoli & 0.026 \\
\hline GR42 & Notio Aigaio & Ermoupoli & 0.418 & ITE3 & Marche & Ancona & 0.029 \\
\hline ES43 & Extremadura & Mérida & 0.417 & ITF2 & Sardegna & Cagliari & 0.029 \\
\hline PL34 & Podlaskie & Bialystok & 0.416 & NL12 & Friesland & Leeuwarden & 0.030 \\
\hline AT34 & Vorarlberg & Bregrenz & 0.411 & ITD2 & Trentino-Alto Adige & Trento & 0.032 \\
\hline
\end{tabular}


Table 9: OLS on Competitive Threat Posed and Faced by Regions

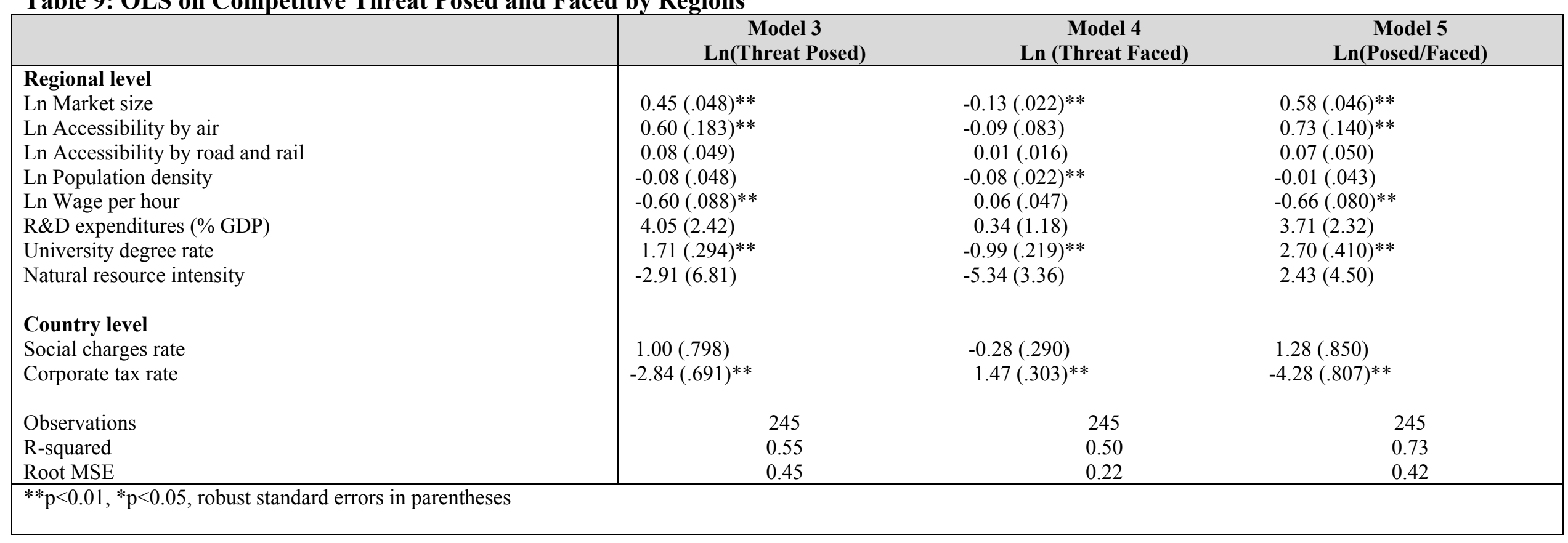

